C A R F W o r king P a p r

\begin{tabular}{|c|}
\hline CARF-F-367 \\
Credibility of management earnings forecasts \\
and future returns \\
Norio Kitagawa \\
Kobe University \\
Akinobu Shuto \\
The University of Tokyo \\
First version: June 2013 \\
This version: May 2016 \\
\hline
\end{tabular}

CARF is presently supported by Bank of Tokyo-Mitsubishi UFJ, Ltd., Dai-ichi Mutual Life Insurance Company, Nomura Holdings, Inc. and Sumitomo Mitsui Banking Corporation (in alphabetical order). This financial support enables us to issue CARF Working Papers.

CARF Working Papers can be downloaded without charge from: http://www.carf.e.u-tokyo.ac.jp/workingpaper/index.html

Working Papers are a series of manuscripts in their draft form. They are not intended for circulation or distribution except as indicated by the author. For that reason Working Papers may not be reproduced or distributed without the written consent of the author. 


\title{
Credibility of management earnings forecasts and future
}

\author{
returns*
}

\author{
Norio Kitagawa \\ Associate Professor \\ Graduate School of Business Administration \\ Kobe University
}

\author{
Akinobu Shuto ${ }^{\mathrm{a}}$ \\ Associate Professor \\ Graduate School of Economics \\ The University of Tokyo
}

First version: June 2013

This version: May 2016

\footnotetext{
${ }^{a}$ Corresponding author: Graduate School of Economics, The University of Tokyo, 7-3-1, Hongo, Bunkyo-ku, Tokyo, 113-0033, Japan. E-mail: shuto@e.u-tokyo.ac.jp

* Acknowledgements: The authors acknowledge the comments received from Gary Chen (discussant) and participants at American Accounting Associations 2014 Annual Meeting, Atlanta, and Tokyo Accounting Workshop at the University of Tokyo. The authors also appreciate the helpful comments and suggestions received from Eli Bartov, Patricia Dechow, Baruch Lev, Shyam Sunder, Douglas J. Skinner, and X. Frank Zhang. All errors are the responsibility of the author.
} 


\title{
Credibility of management earnings forecasts and future returns
}

\begin{abstract}
This study investigates the effect of managerial discretion over their initial earnings forecasts on future performance. First, by estimating the discretionary portion of initial management earnings forecasts (defined as discretionary forecasts) based on the findings of fundamental analysis research, we find that firms with higher discretionary forecasts are more likely to miss their earnings forecast at the end of the fiscal year and revise their forecasts downward to meet their earnings forecasts for the period, suggesting that forecast management through discretionary forecasting produces less credible management forecasts in terms of ex-post realization. Second, by using the hedge-portfolio test and regression analysis, we find that firms with higher discretionary forecasts earn consistently negative abnormal returns, suggesting that investors do not fully understand the implication of discretionary forecasts for the credibility of management earnings forecasts and thus overprice them at the forecast announcement.
\end{abstract}

Keywords: management earnings forecasts, forecast credibility, mispricing, forecast error, forecast revision, Japan

JEL Classification: M41 


\section{Introduction}

Many studies have shown that management earnings forecasts are useful to stock market investors (Patell, 1976; Penman, 1980; Ajinkya and Gift, 1984; Waymire, 1984; Jennings, 1987; Skinner, 1994; Frost, 1997; Hutton et al., 2003; Rogers and Stockton, 2005). Some studies also reveal that management forecasts are systematically upwardly biased, suggesting that managers may be incentivized to bias their initial earnings forecasts (Rogers and Stocken, 2005; Kato et al., 2009; Iwasaki et al., 2015). This study investigates the effect of managerial discretion over initial earnings forecasts on future performance. While many studies have examined the relationship between management earnings forecast errors and current stock returns, fewer have investigated the effect of the credibility of management earnings forecasts on future stock returns. We use a new measure to evaluate the credibility of management earnings forecasts at the forecast announcement date drawn from Iwasaki et al. (2015) to examine the relationship between the measure and future performance. Specifically, by measuring the discretionary portion of an initial management earnings forecast, we examine (1) whether managers' discretionary forecast management reduces the credibility of management earnings forecasts and (2) whether stock investors fully anticipate the implications of forecast management for the credibility of management earnings forecasts.

We use a sample of Japanese firms because the reporting practice for management forecasts in Japan has features useful to our study (Kato et al., 2009; Iwasaki et al., 2015). First, most listed firms report point management forecasts in accordance with the recommendation of The Tokyo Stock Exchange (TSE). Second, listed companies are obliged to report their main accounting earnings for the current year and their earnings 
forecasts for these items for the next year simultaneously. As described in detail later, these factors induce Japanese managers to manage their initial earnings forecasts (Kato et al., 2009; Iwasaki et al., 2015) and thus provide us a useful setting in which to conduct analyses and offer sufficient observations.

This study seeks to better understand the economic consequences of bias in management earnings forecasts. Management forecast announcements, especially in Japan, are used by market participants as an important source of new information. For example, prior studies reveal that stock price reactions around the announcement date are more pronounced for forecast earnings than for actual earnings (Darrough and Harris, 1991; Conroy et al., 1998). Other recent studies show that forecast-based earnings benchmarks at the earnings announcement, referred to as "forecast innovations," ${ }^{1}$ have incremental information content beyond actual earnings surprise measures around the announcement date (Kato et al., 2009; Asano, 2009; Iwasaki et al., 2015).

The significant economic consequence might induce Japanese managers to manage their earnings forecasts. Iwasaki et al. (2015) provide evidence that Japanese firm managers are likely to manage their earnings forecasts to obtain higher stock returns at the earnings announcement date. ${ }^{2}$ Despite the practical importance of management earnings forecasts as

\footnotetext{
1 The forecast innovation for year $t$ is measured as the management forecasts for year $t+1$ minus the actual earnings for year $t$ (Kato et al., 2009; Iwasaki et al., 2015).

${ }^{2}$ For instance, Panasonic Corporation reported 2013 management earnings forecasts of 5 billion JPY on May 11, 2012, which represents an 882 billion JPY increase over the current year (Nihon Keizai Shimbun, May 12, 2012). Its positive forecasts caused the stock price to increase from 570 to 578 (about 1.4\%) at the press release date. On October 31, 2012, however, Panasonic revised its earnings forecasts downward to 765 billion in losses from 5 billion in profits. As a result, its stock price dropped from 514 to 414 (about 19.5\%) by the press release date (Nihon Keizai Shimbun, November 1,2012). This case suggests that managers are likely to report optimistic initial earnings forecasts and that investors appear to overvalue them.
} 
a significant source of investment information, how discretionary forecast management affects future stock performance is unknown. Exploring the relationship between management forecast bias and future stock price could enhance our understanding of stock market efficiency and help investors use management earnings forecasts more efficiently.

Our first research objective, in a preliminary analysis, is to investigate the effect of discretionary forecast management on subsequent forecast errors and revisions. Studies have suggested that Japanese managers are likely to manage their initial earnings forecasts to meet forecast innovations (Kato et al., 2009; Iwasaki et al., 2015). However, it is important to note that forecast innovations include both discretionary and non-discretionary parts. Thus, we decompose forecast innovations into discretionary and non-discretionary portions, referred to as discretionary forecasts and nondiscretionary forecasts, and predict that a higher portion of discretionary management forecasts increases the probability of subsequent forecast errors and revisions. We estimate the discretionary portion of initial management earnings forecasts using a prediction model based on the findings of fundamental analysis research (Lev and Thiagarajan, 1993; Abarbanell and Bushee, 1997; Iwasaki et al., 2015). Consistent with our prediction, we find that firms with higher discretionary forecasts are more likely to miss their earnings forecasts at the end of the fiscal year and to revise their forecasts downward to meet their earnings forecasts during the same period, whereas non-discretionary forecasts are less related to subsequent forecast errors or revisions. These findings imply that management earnings forecasts containing a higher discretionary portion have less ex post realization credibility.

Given the lower credibility of the discretionary forecasts, our next concern is whether 
investors fully understand the implications of discretionary forecasts for the credibility of management earnings forecasts. Thus, our second research objective, which is our main concern, is to examine the relationship between discretionary forecasts and future returns. As the findings on the accruals anomaly imply, if investors naively fail to anticipate the lower credibility of the higher discretionary forecasts, a negative relationship between discretionary forecasts and future abnormal stock returns will occur. Our hedge-portfolio test, comprising a portfolio long in firms in the most negative decile and short in firms in the most positive decile of discretionary forecasts, yields consistently positive abnormal returns. By contrast, we observe no significant association between nondiscretionary forecasts and future abnormal returns. These overall results suggest that the market tends to overestimate the credibility of discretionary forecasts and thus overprices them at the management forecast announcement.

Finally, we conduct two additional analyses concerning alternative explanations for the mispricing of discretionary forecasts. First, we examine the effect of the accruals anomaly on our results. As described above, Japanese firms are expected to report both their net income for the current year and their net income forecasts for the next year simultaneously. If (discretionary) accruals are strongly correlated with discretionary forecasts, our results might be explained with reference to the accruals anomaly. Our additional analysis reveals that discretionary forecasts are still overpriced after we control for the effect of the accruals anomaly on future abnormal returns.

Second, we focus on the alternative explanation for our results based on risk pricing in efficient markets by investigating the abnormal stock returns over the short-window around 
subsequent announcements of management forecast revisions. If investors overreact to the implications of discretionary forecasts, the information released around subsequent forecast revision announcements will cause them to revise their beliefs and prices towards intrinsic values. We find a significant positive relationship between discretionary forecasts and shortwindow returns around subsequent forecast revision announcement dates, suggesting that the abnormal stock returns earned through the trading strategy based on discretionary forecasts are less likely to be caused by incorrectly measured risk.

This study contributes to the literature significantly in several ways. First, we contribute to the accounting anomaly literature by providing evidence on the mispricing of initial management forecasts. Accounting studies have revealed several anomalies based on actual accounting information (Richardson et al., 2010), such as the accruals anomaly (Sloan, 1996; Xie, 2001; Collins and Hribar, 2000; Richardson et al., 2005), the post-earnings announcement drift (Foster et al., 1984; Bernard and Thomas, 1989, 1990; Ball and Bartov, 1996; Livnat and Mendenhall, 2006), and the fundamental analysis (Abarbanell and Bushee, 1997, 1998; Frankel and Lee, 1998). Our study has similarities with accruals anomaly research in that both focus on the attributes of an accounting earnings component and examine their effect on future performance. However, while accruals anomaly studies investigate the effect of the discretionary component of actual earnings on future performance, this study examines the relationship between the discretionary component of management earnings forecasts and future performance. Our study thus makes an incremental contribution to the literature by providing new anomaly evidence based on management earnings forecasts. 
Second, our study advances our understanding of management earnings forecasts. Many studies have investigated the determinants of the credibility of management earnings forecasts and their relationship with the current returns of U.S. firms (Patell, 1976; Penman, 1980; Ajinkya and Gift, 1984; Waymire, 1984; Jennings, 1987; Skinner, 1994; Frost, 1997; Hutton et al., 2003; Rogers and Stockton, 2005) and of Japanese firms (Conroy et al., 1998; Darrough and Harris, 1991; Ota, 2006, 2010; Kato et al., 2009; Iwasaki et al., 2015). However, fewer studies have examined the relationship between the credibility of management earnings forecasts and future returns in terms of the accounting anomaly.

Finally, our results have significant implications for fundamental analysis studies such as Lev and Thiagarajan (1993) and Abarbanell and Bushee (1997, 1998). We estimate discretionary forecasts using a prediction model based on the findings of fundamental analysis research (i.e., fundamental signals). The significant abnormal returns to the discretionary forecasts strategy observed in this study reconfirm the usefulness of the fundamental signals presented in Abarbanell and Bushee (1997, 1998), operating here in another dimension, and suggest that accounting data could provide value-relevant information to the stock market.

The remainder of this paper is organized as follows. Section 2 summarizes the extant research and develops the study's hypotheses. Section 3 explains the variable measurements used in this paper and the research design for testing our hypotheses. Section 4 outlines the sample selection procedure and describes the descriptive statistics. Section 5 reports the empirical results of the relationship between discretionary forecasts and future performance. Section 6 summarizes the results of our additional analyses. Finally, Section 7 concludes the 
study with a summary.

2. Hypothesis development

2.1 Management forecasts reporting practice in Japan

Management earnings forecasting is an important and typical voluntary disclosure in the U.S. In Japan, by contrast, management forecasts are released along with overviews of the main accounting items (known as Kessan Tanshin), which are obliged to by The Tokyo Stock Exchange (TSE). The TSE encourages listed companies to submit a non-audited overview of their main accounting items within 45 days of the end of a fiscal and interim period. The TSE also expects them to include the management forecasts of their main accounting items in this summary. The requirements are as follows (Kato et al., 2009, p.1577):

(1) Listed companies are expected to release point forecasts of annual earnings on each annual earnings announcement date, as well as revisions of these forecasts on interim earnings announcement dates. Thus, managers provide initial forecasts for year $t$ when year $t-1$ earnings are announced and revisions (including confirmations) when the interim earnings are announced.

(2) Managers are expected to provide forecasts for sales, operating income, earnings before extraordinary items and taxes, net income, earnings per share, and dividend per share. 
(3) Forecasts must be updated if there are "significant" revisions in management estimates, defined as changes in sales estimates of $10 \%$ or more and/or changes in earnings estimates of $30 \%$ or more (the "Significance Rule"). In contrast to the initial forecasts encouraged by stock exchange listing rules, these revisions are required under the Act.

Several Japanese management earnings forecast practices differ from those in the U.S. First, management forecasts disclosure is effectively mandated in Japan (Kato et al., 2009; Iwasaki et al., 2015). Although the management forecasts expected by the TSE are a sort of voluntary disclosure, without legal backing, almost all firms provide management earnings forecasts in accordance with the TSE's recommendation. ${ }^{3}$

Second, listed companies are obliged to simultaneously report the main accounting items of the current year and management forecasts of these items on annual earnings announcement dates. Finally, while many U.S. firms tend to provide range-estimated forecasts, Japanese-listed companies provide point-estimated forecasts, ${ }^{4,5}$ which enable us to conduct analyses for a sufficient number of observations. As most listed firms report their initial management forecasts at the beginning of the fiscal year at the same time, we can form all portfolios for the hedge portfolio strategy based on the discretionary forecasts at the

\footnotetext{
3 For example, Kato et al. (2009) show that $93.7 \%$ of their sample $(38,068$ of 40,647$)$ report management forecasts within a sample period between 1997 and 2007, and Iwasaki et al. (2015) indicate that about 95\% of observations $(28,615$ of 30,192) issue their forecasts within a sample period between 1997 and 2009. These findings suggest that management forecasts disclosure in Japan is effectively mandated.

${ }^{4}$ For example, Kasznik (1999) shows that the percentage of point- and range-estimated forecasts are $54.7 \%$ and $45.3 \%$ respectively from 1987 to 1991 . More recently, Kwak et al. (2012) indicate that, of the 8,483 management earnings forecasts between 1997 and 2009, the point- , range- , and other form forecasts are 20.7\%, $72.7 \%$ and $6.6 \%$ respectively.

5 In Japan, only the dividend per share is sometimes reported by a range estimate (Gotoh, 1997; Ota, 2010).
} 
beginning of each fiscal year, which should reduce any biases caused by the differences in issue dates. Furthermore, the features of the point-estimated forecasts are critically important for our study because they enable us to estimate the discretionary forecasts numerically. Thus, the Japanese management forecast system provides a useful setting for the investigation of management earnings forecasts' effect on future performance.

2.2 The hypothesis on the relationship between discretionary forecasts and future earnings The credibility of management earnings forecasts has been a central concern in accounting research because managers have an incentive to bias them (Rogers and Stocken, 2005). Several studies investigate the credibility of management earnings forecasts by identifying the determinants of their systematic bias (Frost, 1997; Rogers and Stockton, 2005; Ota, 2006; Kato et al., 2009). In general, they explore the determinants of earnings forecasts errors at the end of the fiscal year to evaluate the credibility of management earnings forecasts. ${ }^{6}$ Kasznik (1999) examines the management earnings forecasts in terms of earnings management, showing that managers tend to use discretionary accruals and revise their forecasts downward to meet their own forecasted earnings.

Kato et al. (2009) and Iwasaki et al. (2015) are more germane to our study as they examine the credibility of initial management earnings forecasts for a sample of Japanese firms. Managers in Japan are likely to have an incentive to manage their earnings forecasts

\footnotetext{
${ }^{6}$ For details on the determinants of management earnings forecasts, the literature review of Hirst et al. (2008) is useful. They summarize the factors operating when managers decide to issue a forecast and classify them into two broad categories: (1) forecast environment, the features of the legal, regulatory, analyst, and investor environments; and (2) forecaster characteristics, the information asymmetry, pre-commitment to disclosure, firm-specific litigation, managerial incentives, prior forecasting behavior, and proprietary costs.
} 
because previous market-oriented research has indicated that management forecast announcements are used by market participants as an important source of new information. Several recent studies indicate that forecast innovations, the forecast-based earnings benchmark at the earnings announcement, ${ }^{7}$ have incremental information content beyond actual earnings surprise measures around the announcement date (Kato et al., 2009; Asano, 2009; Iwasaki et al., 2015). Further, many studies provide evidence that stock price reactions around the announcement date are more pronounced for forecast earnings than for actual earnings (Darrough and Harris, 1991; Conroy et al., 1998). Finally, analysis based on a valuation framework provided by Ohlson (2001) shows that management forecasts have the highest correlation to and incremental explanatory power for stock prices (Ota, 2010). These results suggest that management earnings forecasts have higher information content than actual annual earnings in the Japanese stock market and might induce Japanese managers to manage their earnings forecasts. ${ }^{8}$

Consistent with this view, Kato et al. (2009) suggest that initial management earnings forecasts for a fiscal year are systematically upward biased and that managers revise their forecasts downward during the fiscal year to meet their forecasts. Iwasaki et al. (2015)

\footnotetext{
7 The forecast innovation for year $t$ is measured as the management forecasts for year $t+1$ minus the actual earnings for year $t$ (Kato et al., 2009; Iwasaki et al., 2015).

8 Iwasaki et al. (2015) identify two additional factors to explain why Japanese managers have a strong incentive to manage their earnings forecasts. First, the costs of forecasts management at the announcement date are expected to be lower than that of other management methods (i.e., earnings management or forecast revisions) to beat the earnings benchmark. This is because: 1) managers have no restriction on the continuous use of forecasts management while accruals-based earnings management is restricted because of the effect of accruals reversion; and 2) discretionary management for initial forecasts is likely to be less perceivable and more difficult to detect. Second, litigation costs in Japan are relatively small compared to those in Western countries (West, 2001; Ginsburg and Hoetker, 2006), which induce managers to conduct forecasts management (Kato et al., 2009).
} 
measure the discretionary portion of initial management forecasts by using the same prediction model used in this study and reveal that managers manage their initial earnings forecasts to meet forecast innovations. Iwasaki et al. (2015) also show that firms with higher discretionary forecasts tend to revise their forecasts downward after issuing their initial forecast.

These results suggest that managers have an incentive to manage their initial forecasts, reducing the managerial incentive to predict their future earnings accurately and thus biasing their earnings forecasts. As a result, forecast management for initial forecasts is very likely to reduce the credibility of initial management earnings forecasts. Thus, we predict that firms with higher discretionary forecasts are likely to have difficulty meeting their forecasts and will thus miss their forecasts at the end of the fiscal year.

H1a: Firms with higher discretionary forecasts are more likely to miss their forecasts at the end of the fiscal year.

Because of their difficulty in meeting their forecasts, managers with high discretionary forecasts may use options other than their actual management activities to meet their forecasts. As indicated by prior studies (Kato et al., 2009; Iwasaki et al., 2015), one option is to revise their forecasts after issuing the initial one. We predict that firms with higher discretionary forecasts tend to revise their forecasts downward during the fiscal year and replicated their analyses for our sample. 
H1b: Firms with higher discretionary forecasts are more likely to revise their forecasts downward during the fiscal year.

2.3 The hypothesis on the relationship between discretionary forecasts and future returns If firms with higher discretionary forecasts are more likely to miss their forecasts and revise their forecasts downward (as per hypotheses 1 and 2), our next concern is to examine whether markets fully understand the implications of such behavior for the credibility of management earnings forecasts. Many studies have indicated that management earnings forecasts are positively associated with current stock returns, attributable to earnings forecasts' ability to summarize value relevant information (Patell, 1976; Penman, 1980; Ajinkya and Gift, 1984; Waymire, 1984; Jennings, 1987; Skinner, 1994; Frost, 1997; Hutton et al., 2003; Rogers and Stockton, 2005). As for Japanese firms, as mentioned earlier, some studies have shown that stock price reactions around the announcement date are more pronounced for management earnings forecasts for year $t+1$ than for actual annual earnings for year $t$, suggesting that management earnings forecasts have higher information content than the actual annual earnings around the announcement date in the Japanese stock market (Darrough and Harris, 1991; Conroy et al., 1998; Ota, 2010). Furthermore, Kato et al. (2009) indicate that forecast innovations are associated with announcement period stock returns after controlling for both an earnings surprise and a dividend surprise measure. Finally, forecast revisions subsequent to the initial forecasts also have a significantly positive association with the announcement period stock returns, indicating that the revisions' announcements can surprise investors (Gotoh, 1997; Kato et al., 2009). Taken together, these results suggest that management 
earnings forecasts indeed have information content, as they influence stock prices. However, the effect of management earnings forecasts on future returns has been less studied. ${ }^{9}$

We can assume two contrary predictions about the consequence of discretionary forecasts. If investors anticipate the implication of discretionary forecasts for the credibility of management earnings forecasts, we can predict that discretionary forecasts are not associated with future abnormal returns. On the other hand, if investors naively fail to understand the implications of the lower credibility of discretionary forecasts, discretionary forecasts will have a negative association with future abnormal returns. In particular, if investors naively ignore the current discretionary forecasts expected to cause forecast errors and revisions, they will be surprised by bad performance announcements in the subsequent periods, leading to negative abnormal returns in the later periods.

The latter explanation, the mispricing hypothesis, is similar to the theoretical explanation of the accruals anomaly (Sloan, 1996; Xie, 2001; Collins and Hribar, 2000; Richardson et al., 2005). The studies reveal that investors overestimate the persistence of accruals that are components of actual earnings and thus overprice these accruals. In addition to the evidence from the U.S. market, studies show that the accruals anomaly exists in the

\footnotetext{
${ }^{9}$ A recent exception is $\mathrm{Ng}$ et al. (2013), which show that more credible earnings forecasts are associated with a smaller post-management forecast drift in return. Although our study is similar to $\mathrm{Ng}$ et al. (2013) in that both studies examine the relationship between the credibility of management forecasts and future returns, our study is clearly different from Ng et al. (2013) in several ways. First, their main purpose is to examine if credible management forecasts could reduce post-management forecast drift in return, which assumes that investors can determine the credibility of management forecasts at the announcement to a certain degree. In contrast, our primary focus is to provide the anomaly evidence relating to management forecasts' lack of credibility. Second, they measure the proxy for the credibility of management forecasts based on 1) forecast characteristics, 2) firm characteristics, and 3) market reaction in order to infer the credibility of a given forecast. However, they do not measure the discretionary portion of management earnings forecasts using numerical forecast data, as this study does.
} 
Japanese stock market (Pincus et al., 2007; Kubota et al., 2010; Leippold and Lohre, 2012). ${ }^{10}$ Given the occurrence of accrual mispricing, we predict that the mispricing hypothesis will also obtain for the relationship between discretionary forecasts and future abnormal returns due to the inference that discretionary management for initial forecasts is less perceptible and more difficult for investors to detect than is earnings management. Because of the recent diffusion of earnings management knowledge, investors can grasp the discretionary accruals through financial statement analysis using the method shown in Jones (1991); thus, the amount of managed earnings could be measured by market participants. However, the lack of a common method of measuring the discretionary portion of management earnings forecasts makes it difficult for investors to detect the discretionary forecasts. Thus, we predict a negative relationship between discretionary forecasts and future abnormal returns.

H2: Firms with higher discretionary forecasts are more likely to experience lower future returns.

\section{Research design}

\subsection{Variable measurement}

Our basic idea behind the discretionary management forecasts is that they can be measured as the difference between forecast innovations and the expected value of change in earnings

\footnotetext{
10 Asano (2002), Enomoto (2003), and Okumura (2003) also provide evidence suggesting the existence of the accruals anomaly in Japan.
} 
for the next year, since forecast innovations correspond to the change in earnings forecasted by managers. Based on this idea, we first estimate the expected value of change in earnings for the next year using the method in Iwasaki et al. (2015). ${ }^{11}$ They adopt an estimation model based on the findings of fundamental analysis research (Lev and Thiagarajan, 1993; Abarbanell and Bushee, 1997, 1998). Specifically, as described in model (1), we estimate the expected (i.e., nondiscretionary) portion of management forecasts by modeling the change in earnings as a function of 1) the prior period's change in earnings, and 2) fundamental signals. $^{12}$

$C R O A_{t}=\alpha+\beta_{1}$ CHGROA $_{t-1}+\sum_{k=1}^{9} \beta_{k} A B$ fundamental signals $k, t-1+\varepsilon_{t}$

where,

$C R O A_{t}=($ net income for year $t-$ net income for year $t-1) /$ total assets at the end of yeart1.

CHGROA $A_{t-1}=($ net income for year $t-1-$ net income for year $t-2) /$ total assets at the end of

\footnotetext{
11 Studies such as Fama and French (2006) and Hou et al. (2012) present alternative earnings expectation model. However, we adopt the model that is similar to Iwasaki et al. (2015) for several reasons. First, one of our contributions is to provide evidence regarding the usefulness of fundamental analysis as mentioned in the introduction section. For this purpose, we need to estimate the expected change in earnings by using only accounting data. Therefore, it is not appropriate to adopt Fama and French (2006) model that includes market or analyst forecasts variables including book-to-market ratio $(\ln B M)$, market value $(\ln M C)$, stock returns $(1 Y$, 2-3Y), analyst consensus forecasts $(I / B)$. Second, we need to estimate the expected value of the change in earnings to estimate discretionary forecasts. However, expectation models by Fama and French (2006) and Hou et al. (2012) are developed to estimate the expected value of the level of earnings.

12 Iwasaki et al. (2015) adopt an estimation model similar to that used by Matsumoto (2002), which estimates the expected portion of analysts' forecasts. Specifically, Matsumoto (2002) estimates the expected analysts' forecasts by modeling the seasonal change in earnings as a function of 1) the prior quarter's seasonal change in earnings and 2) the cumulative excess return of year $t$. Iwasaki et al. (2015) extend this model by adding the fundamental signals variables. We estimate this model for each year. Each sequential variable is winsorized at 1 and 99 percentiles by year.
} 
year $t-1$.

$A B$ fundamental signals $_{t-1}=$ fundamental signals for current fiscal year $t$ proposed by Lev and Thiagarajan (1993) and Abarbanell and Bushee (1997). The detailed definitions of the variables are summarized in the Appendix.

Our estimation model is primarily based on the first-order serial correlation model for the changes in annual earnings in accordance with the findings of prior studies on earnings persistence (Brown and Kennelly, 1972; Freeman and Tse, 1989; Bernard and Thomas, 1990). Thus, we include the current change in $\mathrm{ROA}\left(\mathrm{CHGROA}_{t}\right)$ as an independent variable.

Furthermore, nine fundamental signals variables empirically supported by previous fundamental analysis research (Lev and Thiagarajan, 1993; Abarbanell and Bushee, 1997) are included to improve the explanatory power of the model. The fundamental signals include change in inventory $\left(I N V_{t-1}\right)$, change in accounts receivables $\left(A R_{t-1}\right)$, change in capital expenditures $\left(C A P X_{t-1}\right)$, change in gross margin $\left(G M_{t-1}\right)$, change in selling and administrative expenses $\left(S \& A_{t-1}\right)$, change in effective tax rate $\left(E T R_{t-1}\right)$, change in total accruals $\left(C T A C_{t-1}\right),{ }^{13}$ audit qualification dummy $\left(A Q_{t-1}\right)$, and change in sales revenue per employee $\left(L F_{t-1}\right)$. More detailed definitions of each fundamental signal are summarized in the Appendix. Lev and Thiagarajan (1993) indicate that these signals are significantly associated with contemporaneous stock returns, while Abarbanell and Bushee (1997) demonstrate that the association between signals and contemporaneous returns can be explained by their ability

\footnotetext{
13 As to earnings quality measures, Abarbanell and Bushee (1997) use a dummy variable set to "1" if a firm adopts LIFO and "0" otherwise. We adopt CTAC instead of the LIFO measure since total accruals are expected to be able to more accurately capture earnings quality than a single accounting procedure could.
} 
to predict future earnings. Following the definitions of Lev and Thiagarajan (1993) and Abarbanell and Bushee (1997), fundamental signal variables are defined as having a negative association with future performance. Thus, all these variables are expected to have a negative association with $C R O A_{t}{ }^{14}$

Based on Abarbanell and Bushee $(1997,1998)$, we estimate this model by year and calculate the parameter estimates for each variable. ${ }^{15,16}$ We then apply the parameter estimates derived from the previous year in the model (1) and actual data from the current year to determine the expected value of $C R O A_{t}{ }^{17}$ We define the nondiscretionary portion of management forecast innovations (hereafter "nondiscretionary forecast," or $N D F$ ) as the expected value of $C R O A_{t}$. Specifically, $N D F_{t}$ is described as equation (2) below:

$$
N D F_{t}=\left(\hat{\alpha}_{t-1}+\hat{\beta}_{1 t-1} C H G R O A_{t-1}+\sum_{k=1}^{9} \hat{\beta}_{\mathrm{k} t-1} \text { AB fundamental signals } k, t-1\right)
$$

\footnotetext{
14 In addition to the fundamental signals, Iwasaki et al. (2015) include firm-specific daily excess (marketadjusted) returns that are cumulated from 3 days after the year $\mathrm{t}-2$ earnings announcement to 20 days before the year $t$-1 earnings announcement (CRET) to control for the additional value-relevant information (other than fundamental signals) that managers might use to forecast earnings. We do not add the CRET in our estimation model, and include only fundamental signals. This is because one of our aims is to confirm the usefulness of the fundamental signals in estimating the discretionary forecasts. As an additional analysis, we also estimate the discretionary forecast by using a model that includes CRET. However, the results are consistent with those of the non-CRET model presented later in this study.

15 Untabulated results from estimating equation 1 reveal that the average coefficients on $C H G R O A, I N V, C A P X$, $G M, S \& A, T A C, A Q$, and $L F$ are negative, which is consistent with the results of Aberbanell and Bushee [1997, 1998]. Also, we find that the fundamental signals have incremental explanatory power for the future change in earnings, suggesting the model is reasonably specified. In addition, the mean value of adjusted R-square for model 1 is about $13 \%$, suggesting that our model has reasonable explanatory power.

${ }^{16}$ In the regression on an analysis covering 2006 to 2008, we cannot estimate the parameter of $A Q$ because all $A Q$ observations are " 0 " (i.e., all observations are unqualified opinions). Therefore, we exclude $A Q$ from the regression model covering 2006 to 2008.

17 The estimate of managers' expected forecasts should use only data that would be available to managers in making their forecast. Thus, we use the parameter estimates from the prior firm-year to determine nondiscretionary forecasts $(N D F)$. This procedure is also important in terms of strategic feasibility for the securities investment.
} 
Finally, we define the discretionary portion of management earnings forecasts (hereafter “discretionary forecasts," or $D F)$ by subtracting the nondiscretionary forecasts $\left(N D F_{t}\right)$ for year $t$ from the forecast innovations $\left(F I_{t}\right)$ for year $t$, as described by equation (3) below:

$$
D F_{t}=F I_{t}-N D F_{t}
$$

$F I_{t}$ for year $t$ is measured by the management forecasts for year $t+1$ less the actual earnings for year $t$. Both $N D F_{t}$ and $F I_{t}$ are divided by total assets at the end of year $t-1$. A larger $D F_{t}$ implies the performance of more upward forecast managements. ${ }^{18}$

\subsection{Forecast management and future forecast errors and revisions}

To test hypotheses $1 \mathrm{a}$ and $1 \mathrm{~b}$, we estimate regression models (4) and (5). In estimating the models, we use pooled OLS regressions and report $t$-statistics based on standard errors clustered at the firm and year levels following the analysis in Petersen (2009). ${ }^{19}$

18 As a result of our estimation procedure, management earnings forecasts are classified into forecast innovation and net income; forecast innovations are then classified into discretionary forecasts and nondiscretionary forecasts, as follows (Iwasaki et al., 2015, Figure 1):

\begin{tabular}{|c|c|c|}
\hline \multicolumn{3}{|c|}{ Management earnings forecasts for year $t+1(M F)$} \\
\hline \multicolumn{2}{|c|}{ Forecast innovations for year $t(F I)$} & Net income for year $t$ \\
\hline Discretionary forecasts for year $t(D F)$ & Non-discretionary forecasts for year $t(N D F)$ & Net income for year $t$ \\
\hline
\end{tabular}

Consequently, discretionary forecasts are expected to capture the discretionary portion of management earnings forecasts.

19 For all the following regression analyses, we also report $t$-statistics based on this estimation method. If clustering standard errors do not allow for the inclusion of all our currently included industry dummy variables, we combine at least two industry dummy variables into one industry dummy variable to estimate 
ERROR $_{t+1}=\alpha+\beta_{1} D F_{t}+\beta_{2} N D F_{t}+A B$ fundamental signals $_{t}+F F$ risk factors ${ }_{t}+\varepsilon_{t}$

REVISION $_{t+1}=\alpha+\beta_{1} D F_{t}+\beta_{2} N D F_{t}+$ AB fundamental signals fu $_{t}+F F$ risk factors $t_{t}+\varepsilon_{t}$

where,

$\operatorname{ERROR}_{t+1}=($ actual net income for year $t+1-$ initial management forecasts for year $t+1) /$ total assets at the end of the year $t-1$.

REVISION $_{t+1}=($ the latest management forecasts for year $t+1-$ initial management forecasts for year $t+1) /$ total assets at the end of year $t-1$.

$D F_{t}=$ forecast innovation $\left(F I_{t}\right)$ minus nondiscretionary forecasts $\left(N D F_{t}\right) . \quad F I_{t}=$ (management forecasts for year $t+1$ minus actual net income for year $t$ ) / total assets at the end of year $t-1$.

$N D F_{t}=$ nondiscretionary forecasts / total assets at the end of year $t-1$.

$A B$ fundamental signals $_{t}=$ fundamental signals for current fiscal year $t$ proposed by Lev and Thiagarajan (1993) and Abarbanell and Bushee (1997).

$F F$ risk factors f $_{t}=$ risk factors for current fiscal year $t$ proposed by Fama and French (1993).

Model (4) is used to test hypothesis 1a, that firms with higher discretionary forecasts are more likely to miss their forecasts. For the dependent variable in model (4), we measure management forecast errors for the next year $\left(E R R O R_{t+1}\right)$, defined as the actual net income for year $t+1$ minus the initial management forecasts for year $t+1$, deflated by total assets at

the regression. 
the end of year $t-1$ (e.g., Kato et al., 2009). Our primary concern with the independent variable is discretionary forecasts $\left(D F_{t}\right)$, described in section $3.1 .^{20}$ If higher discretionary forecasts represent less credible management earnings forecasts (as per hypothesis 1), the coefficient on $D F_{t}$ will be negative. We employ regression model (5) to test hypothesis $1 \mathrm{~b}$, that firms with higher discretionary forecasts are more likely to revise their forecasts downward during the fiscal year. REVISION ${ }_{t+1}$ is defined as the latest management forecasts for year $t+1$ minus initial management forecasts for year $t+1$, deflated by total assets at the end of year $t-1$ (e.g., Bartov et al., 2002; Brown and Pinello, 2007; Das et al., 2011; Iwasaki et al., 2015). If hypothesis $1 \mathrm{~b}$ is supported, the coefficient on $D F_{t}$ in model (5) will be negative.

To compare with the results of the discretionary forecasts, we also include nondiscretionary forecasts $\left(N D F_{t}\right)$ as an independent variable to capture the effect of the nondiscretionary portion of management earnings forecasts on future earnings changes. ${ }^{21}$ Because nondiscretionary forecasts are expected to not have a negative effect on the credibility of management earnings forecasts, we predict that there are no significant

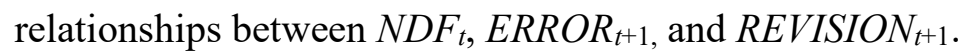

In addition, we control for several variables that explain future firm performance. First, we include nine fundamental signals for the current fiscal year $t$ (AB fundamental signals $\left._{t}\right)$, as defined in section 3.1.: INV $t, A R_{t}, C A P X_{t}, G M_{t}, S \& A_{t}, E T R_{t}, C T A C_{t}, A Q_{t}$, and $L F_{t}$.

\footnotetext{
${ }^{20}$ We also conduct additional analyses in which the discretionary forecasts variable is defined as a decile rank variable, but the results are consistent with those of our study.

21 It should be noted that we used the fundamental signals variables as an economic factor to estimate the $N D F_{t}$ in section 3.1, which might cause the high correlation between the fundamental signals variables and $N D F_{t}$, and thus bias the estimation of our regression models. Although the correlations reported in Table 3 do not reveal a strong correlation between these two variables, we confirm the robustness of our results by estimating the models excluding $N D F$ and the fundamental signals variables, respectively, in our all regression models. The results are consistent with those reported in this study.
} 
As described in section 3.1., these variables are expected to have a negative association with future earnings, and we thus expect that all these variables will be negatively related to future forecast errors and revisions.

Finally, we control for Fama-French risk factors $\left.(F F \text { risk factors })_{t}\right)$ of market beta $\left(B E T A_{t}\right)$, firm size $\left(S I Z E_{t}\right)$, and book-to-market ratio $\left(B M_{t}\right) . B E T A_{t}$ is calculated with a market model using monthly returns over the 60 month period ending at the current fiscal year $t$. $S I Z E_{t}$ is the natural log of the market value of equity at the end of year $t$, and $B M_{t}$ corresponds to the book value of equity at the end of year $t$ divided by the market value of equity at the end of year $t$. These variables are expected to represent unknown risk factors and are positively correlated to future expected returns (Fama and French, 1993). The expected signs of the coefficients on $B E T A_{t}$ and $B M_{t}$ are positive, and $S I Z E_{t}$ is negative.

\subsection{Forecast management and future returns}

To test hypothesis 2 , that firms with higher discretionary forecasts are more likely to earn lower future returns, we first conduct an analysis by using a hedge-portfolio test method commonly used for testing the mispricing of accounting information (Sloan, 1996; Xie, 2001; Frankel and Lee, 1998). Specifically, we group firms into portfolio deciles each year based on their ranking of discretionary forecasts and form a hedge portfolio that takes a long position in the most negative discretionary forecasts decile and a short position in the most positive discretionary forecasts decile. We investigate the hedge portfolio returns starting at 4 months after the fiscal year end and running to the thirty-sixth month for evidence of price 
correction. ${ }^{22}$ Hedge portfolio returns are calculated by using 12-month size-adjusted buyand-hold returns, as defined below. If investors overprice discretionary forecasts in the portfolio formation year, as hypothesis 2 suggests, the hedge portfolio returns in subsequent years will be positive due to the investors' delayed price response to information about the credibility of management forecasts.

In addition, to control for the effect of other factors on abnormal stock returns, we then investigate the association between the subsequent stock returns and discretionary forecasts by using regression model (6) below:

$B H A R 12_{t+1}=\alpha+\beta_{1} D F_{t}+\beta_{2} N D F_{t}+A B$ fundamental signals fu $_{t}+F F$ risk factors ${ }_{t}+\varepsilon_{t}$

where,

BHAR $12_{t+1}=$ size-adjusted abnormal return calculated as the firms' buy-and-hold return (including dividends) beginning at the start of the 4 month after the fiscal year end $t$ and ending at the end of the 3 month after the fiscal year end $t+1$ minus the buy-and-hold return on a size-matched portfolio over the same period.

The dependent variable BHAR $12_{t+1}$ represents the subsequent size-adjusted abnormal return, which is the firm's buy-and-hold return minus the buy-and-hold return on a value

22 Our sample consisted of firms whose fiscal years end on March 31; their earnings (presented in the summary of financial results that is referred to as Kessan-Tanshin) are generally announced by mid-May, to comply with the requirement of the Tokyo Stock Exchange. The financial statements of these firms are disclosed in June (at the latest), so that the required shareholders' general meeting can be held by the end of June (Kubota et al., 2010, p.138). Therefore, we formed ranked portfolios on July 1. 
weighed portfolio of firms in the same-sized deciles. Size deciles are determined by the distribution of market values of all the firms listed in the first section of the Tokyo Stock Exchange (except for institutional firms). ${ }^{23}$ The market values of equity are calculated based on the stock price at the end of August for each year. ${ }^{24}$ BHAR $12_{t+1}$ is calculated over the 12 month holding periods, beginning at the start of 4 month after the current fiscal year end.

We focus on the coefficient on $D F_{t}$ in model (6) to test hypothesis 2 . The negative coefficient on $D F_{t}$ means that investors do not fully understand the credibility of discretionary forecasts and overestimate it, consistent with hypothesis 2 . On the other hand, if investors anticipate the implication of discretionary forecasts for the credibility of management forecasts, we expect that $D F_{t}$ is not significantly associated with $B H A R 12_{t+1}$. Furthermore, to examine the effect of nondiscretionary forecasts on future stock returns, we include $N D F_{t}$ as an independent variable and predict that there is no significant association between $N D F_{t}$ and BHAR $12_{t+1}$.

Finally, we include $A B$ fundamental signals $s_{t}$ and $F F$ risk factors $s_{t}$ as control variables, which are the same as those of regression models (4) and (5). AB fundamental signalst are expected to have negative correlations with $B H A R 12_{t+1}$. The expected sign of the coefficients on $B E T A_{t}$ and $B M_{t}$ are positive, and $S I Z E_{t}$ is negative.

4. Sample selection and descriptive statistics

\footnotetext{
23 Preferred securities, J-REIT (Japanese real estate investment trust), and the special investment corporation are also excluded.

24 Therefore, we rebalance the size deciles at every end of August. Firms newly listed on the stock exchange at the beginning of September are first included in the rebalance of the size deciles at the end of August the next year.
} 


\subsection{Sample selection procedure}

Table 1 summarizes our sample selection procedure. The necessary data on financial statements, management forecasts, and stock price are all obtained from the Nikkei NEEDS Financial QUEST database. After excluding financial institutions (banks, securities companies, and insurance companies) and other financial institutions (credit and leasing), we identify the listed companies that report consolidated financial statements for the calendar years from 2003 to 2009. Our initial sample consists of 18,957 firm-year observations. For this sample period, we delete firm-year observations if 1) their fiscal year does not end in March, 2) there are changes of accounting months within firm-years in our analyses, 3) there are missing data needed to calculate forecast innovations, forecast errors, and forecast revisions, or 4) there are missing financial statements and stock data needed for our analyses. These criteria yield a final sample size of 9,706 firm-year observations. The untabulated result shows that about $93 \%$ of observations $(17,577$ of 18,957$)$ in our initial sample include forecast data, suggesting that most Japanese firms issue forecast information. This is consistent with the findings of the studies that have argued that Japanese forecasting practices are effectively mandated (Kato et al., 2009; Iwasaki et al., 2015).

\subsection{Descriptive statistics}

Table 2 provides the descriptive statistics for our sample. To avoid outlier effects, we winsorize all sequential variables at $1 \%$ and $99 \%$. The table shows that, while the average of the discretionary forecasts $\left(D F_{t}\right)$, the variable of our primary concern, is 0.007 , the average of nondiscretionary forecasts $\left(N D F_{t}\right)$ is 0.003 . This means that about $70 \%$ of forecast 
innovations $\left(F I_{t}\right)$ consist of unexpected portions (i.e., discretionary forecasts). The untabulated result also reveals that about $24 \%$ of initial management earnings forecasts are composed of discretionary forecasts. It also shows that the forecast error $\left(E R R O R_{t+1}\right)$ average is -0.008 , suggesting that the net income forecasts in Japan are generally optimistic. We also find that the forecast revisions $\left(\right.$ REVISION $\left._{t+1}\right)$ average is relatively small and negative (0.008), indicating that, on average, managers revise their earnings forecasts downward during the fiscal year.

Table 3 reports the Pearson and Spearman rank-order correlation matrix among the variables used in our regression analyses. We find that $D F_{t}$ is significantly and negatively associated with $E_{R R O R_{t+1}}$ and $R E V I S I O N_{t+l}$, respectively, in both correlation analyses, suggesting that firms with higher discretionary forecasts tend to report negative forecast errors at the end of the fiscal year and revise their earnings forecasts downward during that year, consistent with hypotheses $1 \mathrm{a}$ and $1 \mathrm{~b}$. Consistent with hypothesis 2 , we find that $D F_{t}$ is significantly and negatively associated with $B H A R 12_{t+1}$, indicating that firms with higher discretionary forecasts are more likely to earn lower future returns in year $t+1$.

\section{Main results}

5.1 The results on the relationship between discretionary forecasts and forecast errors and revisions

To test the effect of forecast management on forecast errors and revisions, we group firms into ten equal-number portfolios (deciles) each year based on the magnitude of the 
discretionary forecasts. Table 4 reports the average of $E R R O R_{t+l}\left(\right.$ REVISION $\left._{t+l}\right)$ for each $D F_{t}$ decile and the average $E_{R R O R_{t+1}}\left(\operatorname{REVISION}_{t+1}\right)$ of the highest-minus-lowest $D F_{t}$ portfolio deciles. It shows that the higher portfolio deciles have fewer forecast errors and revisions than those of the lower portfolio deciles. For example, we find that, while the highest portfolio has an average $E R R O R_{t+1}$ of -0.023 , the lowest portfolio has an average $E R R O R_{t+1}$ of -0.007 . The table also reveals that the average $E_{R R O R_{t+1}}$ and $R E V I S I O N_{t+l}$ of the highestminus-lowest $D F$ portfolio deciles are -0.016 and $-0.015(t$ value $=-8.318$ and -8.011$)$, respectively, consistent with hypotheses $1 \mathrm{a}$ and $1 \mathrm{~b}$.

To further test hypotheses $1 \mathrm{a}$ and $1 \mathrm{~b}$, we estimate regression model (4) to examine the effect of discretionary forecasts on future earnings and report the results in Table 5. It shows that discretionary forecasts are significantly associated with forecast errors in the expected way. Consistent with hypothesis $1 \mathrm{a}$, the coefficient on $D F_{t},-0.141$, is significantly negative at a level less than $0.01(t$ value $=-4.684)$. On the other hand, the coefficient on $N D F_{t}$ is less significant, meaning that the nondiscretionary forecasts variable is less associated with forecast errors. ${ }^{25}$

Table 6 reports the regression result of model (5) concerning the relationship between discretionary forecasts and forecast revisions. We find that discretionary forecasts are significantly associated with forecast revisions. Specifically, we find that the coefficient on $D F_{t},-0.129$, is significantly negative at a level less than $0.01(t$ value $=-5.236)$, consistent

\footnotetext{
25 However, note that this result is not robust. As shown in table 3, correlation matrix between $N D F_{t}$ and ERROR $_{t+1}\left(\right.$ REVISION $\left._{t+1}\right)$ is positive. In addition, when we estimate regression model (4) and (5) without discretionary forecasts, the coefficient on $N D F_{t}$ become positive $(0.026$ and 0.026$)$ and insignificant $(t$ value $=0.515$ and 0.540 )
} 
with hypothesis $1 \mathrm{~b}$. By contrast, the coefficient on nondiscretionary forecasts are significantly negative at only $10 \%$ level. In both models in Table 5 and 6 , consistent with our prediction, the coefficients on $C A P X_{t}$ and $C T A C_{t}$, are negative. The coefficient on $S_{Z} E_{t}$ is positive, suggesting that large firm provide less optimistic forecasts. ${ }^{26}$

These results suggest that firms with high discretionary forecasts are more likely to miss their earnings forecasts at the end of a fiscal year and then revise their forecasts downward during that year; thus, forecast management through discretionary forecasts reduce the credibility of management earnings forecasts. These findings also imply that the credibility of discretionary forecasts is lower than that of nondiscretionary forecasts.

5.2 The results on the relationship between discretionary forecasts and future returns To test hypothesis 2, as described in section 3.2., we form a hedge portfolio that is long in the most negative discretionary forecasts and short in the most positive discretionary forecasts. Table 7 summarizes the average size-adjusted abnormal return for each discretionary forecasts decile and the size-adjusted abnormal return for the hedge portfolio based on $D F_{t}$. We find that, while the size-adjusted returns for the most positive discretionary forecasts decile are all negative in 6 months (-0.019), 12 months (-0.014), 24 months (-0.006), and 36 months $(-0.019)$, those for the most negative discretionary forecasts decile are all positive in 6 months (0.021), 12 months (0.041), 24 months (0.073), and 36 months (0.085), respectively. The size-adjusted abnormal returns for the highest-minus-lowest hedge

\footnotetext{
26 This is consistent with that of prior studies. For example, Ota (2006) argues that managers of large firms regard management forecasts as the commitments to stakeholders and report conservative forecasts to attain the forecasts.
} 
portfolio are $0.041(t$ value $=3.754)$ in 6 months, and $0.055(t$ value $=3.648)$ in 12 months. ${ }^{27}$ Interestingly, abnormal returns still occur in year $t+2$ and $t+3$ though they are smaller than that in year $t+1$ : hedge portfolio returns for 24 and 36 months are $0.080(t$ value $=3.919)$ and 0.103 ( $t$ value $=4.104)$, respectively. These results are consistent with the market's overestimation of the credibility of discretionary forecasts and its overpricing of it in year $t$.

To compare with these results, we also form a hedge portfolio based on nondiscretionary forecasts $\left(N D F_{t}\right)$. The size-adjusted abnormal returns for the highest-minuslowest hedge portfolio ranked by $N D F_{t}$ are $-0.22(t$ value $=-2.032),-0.020(t$ value $=-1.339)$, $-0.014(t$ value $=-0.680)$, and $-0.015(t$ value $=-0.608)$, respectively. Thus, the size-adjusted abnormal returns for the nondiscretionary forecasts-based hedge portfolio are not significantly positive, inconsistent with the results of the hedge portfolio based on discretionary forecasts.

To further illustrate the pattern of returns in relation to forecast management, Figure 1 plots the size-adjusted abnormal returns over 36 months starting 4 months after fiscal year end for the highest and lowest portfolios in Panel A and the hedge portfolio in Panel B. In Panel A, we observe a generally upward (downward) trend in abnormal returns for the lowest (highest) portfolio. The graph in Panel B shows the hedge portfolio returns to be consistently positive throughout the analytical period, with a clearly upward trend. It should be noted that

\footnotetext{
27 In addition to the subsequent 12-month size-adjusted buy-and-hold returns, we also consider that the result on the subsequent six-month size-adjusted buy-and-hold returns is important. As explained in section 2.1, managers are expected to provide forecast revisions (including confirmation) when the subsequent interim earnings are announced. Investors who fail to see through the discretionary forecasts at the earnings announcement date might learn the consequences of discretionary forecasts through the forecast revisions in the interim earnings report. The analysis of the relationship between the subsequent six-month returns and discretionary forecasts is expected to capture this effect.
} 
in Panel B, the hedge portfolio returns have a rapid upward trend until month 10 (i.e., 0.070), but they significantly drop after that month. This is because realized earnings are announced in month 10 in the Kessan-Tanshin as described in footnote 18. This graphical evidence conforms to the statistical findings in Table 7.

Next, we estimate regression model (6) that controls for the effect of other factors on future returns. Table 8 reports the regression results. We find that discretionary forecasts are significantly and negatively associated with the size-adjusted abnormal returns in year $t+1$. The coefficient on $D F_{t},-0.631$, is significantly negative at a level below 0.01 ( $t$ value $=$ 4.728). On the other hand, the coefficient on $N D F_{t}$ is not significant, meaning that nondiscretionary forecasts are not significantly associated with the size-adjusted abnormal return in year $t+1$ and thus that the market does not misprice nondiscretionary forecasts. With respect to the control variable, $I N V_{t}, C A P X_{t}, S \& A_{t}, C T A C_{t}, A Q_{t}, L F_{t}, B E T A_{t}$, and $B M_{t}$ have their expected signs, but only $A Q_{t}$ and $B M_{t}$ are statistically significant at the conventional levels. These findings are consistent with the portfolio results reported in Table 7. Overall, the results in this section suggest that investors cannot fully anticipate the implication of discretionary forecasts for their credibility and thus overprice discretionary forecasts in the portfolio formation year, consistent with hypothesis $2 .^{28}$

6. Additional analysis

6.1 Accrual anomaly

${ }^{28}$ Considering its importance in our study (see note 27), we estimate the regression model using six-month size-adjusted buy-and-hold returns as the dependent variable and obtain consistent results: the coefficient on $D F_{t}$ is significantly negative at a level below 0.01 , while the coefficient on $N D F_{t}$ is not significant. 
In this section, we conduct additional analyses concerning the two alternative explanations for our main findings. First, we focus on the accruals anomaly. As exemplified by Sloan (1996), much of the literature on accruals anomaly show that stock prices do not fully understand the difference in the persistence of accruals and cash flow components of current earnings until their impacts appear in future earnings (e.g., Sloan, 1996; Xie, 2001; Collins and Hribar, 2000; Richardson et al., 2005). For example, Xie (2001) finds that discretionary accruals are less persistent than are nondiscretionary accruals and that discretionary accruals are more predictable for future returns. As stated above, listed firms in Japan are obliged to report their actual earnings for the current year and management earnings forecasts for the next year simultaneously. If the discretionary accruals and discretionary forecasts correlate, ${ }^{29}$ our findings may be explicable through the accruals anomaly.

Therefore, we investigate whether our findings on discretionary the forecasts anomaly is distinct from the mispricing of accruals (discretionary accruals). To this end, we estimate models (7) and (8), controlling for the effects of total accruals $\left(T A C_{t}\right)$ or discretionary accruals $\left(D A C_{t}\right)$ on future abnormal returns:

$$
\begin{aligned}
& \text { BHAR } 12_{t+1}=\alpha+\beta_{1} D F_{t}+\beta_{2} N D F_{t}+\beta_{3} T A C_{t}+\text { AB fundamental signals } t \\
& \quad+\text { FF risk factors }{ }_{t}+\varepsilon_{t+1} \\
& {\text { BHAR } 12_{t+1}=\alpha+\beta_{1} D F_{t}+\beta_{2} N D F_{t}+\beta_{3} D A C_{t}+\text { AB fundamental signals }}_{t}
\end{aligned}
$$

\footnotetext{
29 For example, Gong et al. (2009) and Xu (2010) indicate that there is a positive association between current year accruals and the management forecasts error in the subsequent year. As an interpretation of the results, they argue that managers' imperfect business assessments influence both accruals generation and earnings forecasts.
} 
where,

$T A C_{t}=$ total accruals for year $t /$ total assets at the end of year $t-1 .{ }^{30}$

$D A C_{t}=$ discretionary accruals for year $t$ estimated using the model in Dechow et al. $(1995) \cdot{ }^{31}$

All other variables are already defined. Table 9 presents the regression result of models (7) and (8). The coefficients on $T A C_{t}$ and $D A C_{t}$ are significantly negative at less than $1 \%$ level, indicating an accruals (discretionary accruals) anomaly in the Japanese stock market. ${ }^{32}$ More importantly, the coefficients on $D F_{t}$ in both columns remain significantly negative at a less than $1 \%$ level even after controlling for the effects of $T A C_{t}$ and $D A C_{t}$. Therefore, we conclude that the relationship between discretionary forecasts and the subsequent size-adjusted abnormal returns is not fully explained by the effects of the accruals anomaly. ${ }^{33}$

\footnotetext{
30 Total accruals are calculated as follows. Total accruals $=$ (change in current assets - change in cash and deposits) - (change in current liabilities - change in financing items) - (change in allowance for doubtful debts + change in provision for retirement benefits or provision for retirement allowance + change in provision for directors' retirement benefits + change in other long-term provision + depreciation). Financing items $=$ change in short-term loans payable + change in commercial papers + change in current portion of long-term loans payable + change in current portion of straight bonds and convertible bonds.

31 Nondiscretionary accruals are estimated cross-sectionally for each industry in a given year using the Nikkei industry classification code (Nikkei gyousyu chu-bunrui).

32 These results are consistent with those of prior studies on the accruals anomaly in Japan (e.g., Pincus et al., 2007; Kubota et al., 2010; Leippold and Lohre, 2012).

33 As an additional analysis, we examine the joint effect of discretionary forecasts and total accruals (discretionary accruals) on subsequent size-adjusted returns. Specifically, we use a contingency table of abnormal returns earned from portfolios constructed by grouping firms according to $D F_{t}$ and $T A C_{t}\left(D A C_{t}\right)$. As a result, we find that firms with the highest $D F_{t}$ and $T A C_{t}\left(D A C_{t}\right)$ generate the lowest abnormal return, (0.069 , and -0.047 , respectively) whereas firms with the lowest $D F_{t}$ and $T A C_{t}\left(D A C_{t}\right)$ generate the highest abnormal return ( 0.075 and 0.059 , respectively). The hedge portfolio returns in joint $D F_{t}$ and $T A C_{t}\left(D A C_{t}\right)$ strategies are 0.144 and 0.106 , respectively, larger than each individual strategy. These results suggest that the discretionary forecasts anomaly is distinct from the accruals anomaly.
} 


\subsection{Risk hypothesis}

The other competing explanation for our results involves compensation for risk. Our finding that discretionary forecasts are negatively associated with the subsequent size-adjusted abnormal returns is consistent with our hypothesis (i.e., the mispricing hypothesis) that investors do not accurately measure the credibility of initial management forecasts and thus overprice the discretionary forecasts. On the other hand, the efficient market hypothesis posits an alternative explanation based on the risk compensation (i.e., risk hypothesis) notion that the changes in the risk information contained in discretionary forecasts might cause the significant relationship between discretionary forecasts and future stock returns. To address this issue, we estimate regression model (9) to test which explanation is more likely to be true, as shown below:

FRRET $_{t+1}=\alpha+\beta_{1} D F_{t}+\beta_{2} N D F_{t}+A B$ fundamental signals $s_{t}+F F$ risk factors fu $_{t}+\varepsilon_{t}$

where,

$F R R E T_{t+1}=$ the sum of the size-adjusted abnormal return around forecast revisions announced for year $t+1$. Size-adjusted abnormal returns around forecast revision announcements are measured as the buy-and-hold returns over the 3-day window surrounding each forecast revision announcement (days from " 0 " to " +2 ") minus the buy-and-hold returns on a size-matched portfolio over the same window. 
As a dependent variable, we measure the stock returns of forecast revisions $\left(F R R E T_{t+1}\right)$, which is the sum of the size-adjusted buy-and-hold returns over the 3-day window surrounding management forecast revisions announced for year $t+1 .{ }^{34}$ The definition of the size-matched portfolio used to calculate the expected stock returns is the same as that described in section 3.3. Firms that do not revise their forecasts during the period are excluded from the sample in this analysis. ${ }^{35}$ As a result, our sample in this analysis consists of 6,930 firm-year observations.

Consistent with our mispricing hypothesis, if investors overestimate the implications of discretionary forecasts for the credibility of management forecasts, the announcements of subsequent forecast revisions will be a surprise for investors and cause them to modify their misvaluations of the initial management forecasts. Therefore, under the mispricing hypothesis, $D F_{t}$ will be expected to have a negative association with $F R R E T_{t+l}$. On the other hand, if the risk hypothesis is supported, we expect that $D F_{t}$ will not have a significant correlation with FRRET $T_{t+1}$.

As a preliminary analysis, we describe the size-adjusted abnormal return around subsequent forecast revision announcement for $D F_{t}$ portfolio in Table 10. Firms in a higher (lower) $D F_{t}$ portfolio experience lower (higher) abnormal returns around the forecast revision

\footnotetext{
34 If firms revise their forecasts one time, $F R R E T_{t+1}$ corresponds to the size-adjusted abnormal return surrounding management forecast revision announcement date. If firms revise their forecasts more than one time, $F R R E T_{t+1}$ is defined as the sum of the size-adjusted abnormal return surrounding each management forecast revision announcement date.

35 If firms do not revise their forecasts during the period, investors might have the information about the credibility of the initial management forecasts through the earnings announcement at the fiscal year end. As an additional analysis, we define the $F R R E T_{t+1}$ of firms that do not revise their forecasts as the size-adjusted abnormal return around earnings announcement (days from “ 0 " to “ +2 ") for the next year and re-estimate equation ( 9 ) by adding them to the sample. We thereby confirm the robustness of our findings.
} 
announcement day, consistent with the mispricing hypothesis. Furthermore, a comparative analysis of the magnitudes of hedge-portfolio returns in Table 7 and Table 10 indicates that the abnormal returns earned by the hedge portfolio based on the discretionary forecasts concentrate in the days around the announcement of subsequent forecast revisions. Specifically, about $33 \%(=0.018 / 0.055)$ of the hedge portfolio return is clustered in the 3 days even though the announcement period windows employed in Table 10 contain less than $10 \%$ of the total trading days in Table $7 .{ }^{36}$

Table 11 presents the regression results of the size-adjusted abnormal returns around subsequent forecast revision announcements for discretionary forecasts. The coefficient on $D F_{t}$ is significantly negative at a less than 0.01 level, suggesting that firms with higher (lower) $D F_{t}$ earn lower (higher) stock returns at the announcements of forecast revisions. These results are consistent with the mispricing hypothesis, rather than the risk hypothesis, presented in our main analysis.

\section{Conclusion}

This study investigates the effect of managerial discretion over initial earnings forecasts on future performance. By estimating the discretionary portion of initial management earnings forecasts based on the findings of fundamental analysis research, we examine (1) whether the use of discretionary forecasting reduces the credibility of management earnings forecasts

\footnotetext{
36 In our sample, management forecast revisions per fiscal year are about 2.09 times on average and 8 times at a maximum. Therefore, the announcement period windows are 6.27 days on average and 24 days at a maximum.
} 
and (2) whether stock investors fully anticipate the implication of discretionary forecasts for the credibility of management earnings forecasts.

First, we hypothesize and find that firms with higher discretionary forecasts are more likely to miss their earnings forecast at the end of the fiscal year and revise their forecasts downward to meet their earnings forecasts during that period, suggesting that forecast management through discretionary forecasts leads to less credible management forecasts in terms of ex-post realization.

Second, our hedge-portfolio test, with a portfolio long in firms in the most negative decile and short in firms in the most positive decile of discretionary forecasts, yields consistently positive abnormal returns, suggesting that investors fail to fully understand the implication of high discretionary forecasts for the low credibility of management earnings forecasts and thus overprice them at the forecast announcement.

Finally, we conduct two additional analyses to test the alternative hypotheses, the accruals anomaly hypothesis and the risk hypothesis, which reveal that, after controlling for the effect of the accruals anomaly and firms' future abnormal returns risk, the mispricing of discretionary forecasts still occurs.

This study contributes to the literature on the credibility of management earnings forecasts and market efficiency in several ways. Our study contributes to the accounting anomaly literature by providing new anomaly evidence concerning the mispricing of initial management earnings forecasts. This study also advances our understanding of management earnings forecasts by revealing the effect of management earnings forecasts' credibility and discretion on future performance. Finally, our results show the usefulness of the fundamental 
analysis for estimating the reliability of management earnings forecasts.

Our study raises several issues for future research. First, although we measure discretionary forecasts using the findings of fundamental analysis, future research might develop a better proxy for them. Second, we present that the hedge portfolio returns are significant for all three years after the portfolio formation date. Future research could explore the reason why the abnormal returns persist for up to 36 months. Third, we conduct additional analyses to verify our mispricing hypothesis, but it is difficult to completely consider all the unknown risk factors. Future research could examine other dimensions or forms of market mispricing. 
References

Abarbanell, J. S., and B. J. Bushee. 1997. Fundamental analysis, future earnings, and stock prices. Journal of Accounting Research 35(1): 1-24.

Abarbanell, J. S., and B. J. Bushee. 1998. Abnormal returns to a fundamental analysis strategy. The Accounting Review 73(1): 19-45.

Ajinkya, B. B., and M. J. Gift. 1984. Corporate managers' earnings forecasts and symmetrical adjustments of market expectations. Journal of Accounting Research 22(2): 425-444.

Asano, N. 2002. Kaikeirieki no shitsutekisai to shihonshijo. in Yamaji, H. (eds), Makuro kaikeiseisaku no hyoka. Kobe Economic \& Business Research Series (written in Japanese).

Asano, T. 2009. Keieisya no gyoseki yosou to shijyou no hyouka. In Zittai bunseki nihonno kaikei syakai, edited by Y. Kurokawa, Tokyo: Chuokeizai-sha (in Japanese).

Ball, R., and E. Bartov. 1996. How naïve is the stock market's use of earnings information? Journal of Accounting and Economics 21(3): 319-337.

Bartov, E., D. Givoly, and C. Hayn. 2002. The rewards to meeting or beating earnings expectations. Journal of Accounting and Economics 33(2): 173-204.

Brown, L. D., and A. S. Pinello. 2007. To what extent does the financial reporting process curb earnings surprise games? Journal of Accounting Research 45(5): 947-981.

Bernard, V. L., and J. K. Thomas. 1989. Post-earnings-announcement drift: Delayed price response or risk premium? Journal of Accounting Research 27(Supplement): 1-36.

Bernard, V. L., and J. K. Thomas. 1990. Evidence that stock prices do not fully reflect the implications of current earnings for future earnings. Journal of Accounting and 
Economics 13 (4): 305-340.

Brown, P., and J. W. Kennelly. 1972. The informational content of quarterly earnings: An extension and some further evidence. Journal of Business 45(3): 403-415.

Collins, D. W., and P. Hribar. 2000. Earnings-based and accrual-based market anomalies: One effect or two? Journal of Accounting and Economics 29(1): 101-123.

Conroy, R., K. Eades, and R. Harris. 1998. Fundamental information and share prices in Japan: Evidence from earnings surprises and management predictions. International Journal of Forecasting 14(2): 227-244.

Darrough, M., and T. Harris. 1991. Do management forecasts of earnings affect stock prices in Japan? in W. T. Ziemba, W. Bailey, and Y. Hamao (eds), Japanese Financial Market Research, North Holland.

Das, S., K. Kim, and S. Patro. 2011. An analysis of managerial use and market consequences of earnings management and expectation management. The Accounting Review 86(6): $1935-1967$.

Dechow, P. M., N. V. Khimich, and R. G. Sloan. 2011. The accrual anomaly. Working paper.

Dechow, P. M., R. G. Sloan, and A. P. Sweeney. 1995. Detecting earnings management. The Accounting Review 70 (2): 193-225.

Desai, H. M., S. Rajgopal, and M. Venkatachalam. 2004. Value-glamour and accruals mispricing: One anomaly or two? The Accounting Review 79(2): 355-385.

Enomoto, M. 2003. Discretionary accruals and future stock returns. Shizuoka Univ. Repos., 7(3-4): 145-168 (written in Japanese).

Fairfield, P. M., J. S. Whisenant, and T. L. Yohn. 2003. Accrued earnings and growth: 
Implications for future profitability and market mispricing. The Accounting Review 78(1): 353-371.

Fama, E., and K. French. 1993. Common risk factors in the returns on stocks and bonds. Journal of Financial Economics 33(1): 3-56.

Fama, E., and K. French. 2006. Profitability, investment and average returns. Journal of Financial Economics 82(3): 491-518.

Foster, G., C. Olsen, and T. Shevlin. 1984. Earnings releases, anomalies, and the behavior of security returns. The Accounting Review 59(4): 574-603.

Frankel, R., and C. M. C. Lee. 1998. Accounting valuation, market expectation, and crosssectional stock returns. Journal of Accounting and Economics 25(3): 283-319.

Freeman, R. N., and S. Tse. 1989. The multiperiod information content of accounting earnings: Confirmations and contradictions of previous earnings reports. Journal of Accounting Research 27: 49-79.

Frost, C. 1997. Disclosure policy choices of UK firms receiving modified audit reports. Journal of Accounting and Economics 23(2): 163-187.

Hafzalla, N., R. Lundholm, and E. Van Winkle. 2011. Percent accruals. The Accounting Review 86(1): 209-236.

Hirst, D. E., L. Koonce, and S. Venkataraman. 2008. Management earnings forecasts: A review and framework. Accounting Horizons 22(3): 315-338.

Hou, K., M. A. Van Dijk, and Y. Zhang. 2012. The implied cost of capital: A new approach. Journal of Accounting and Economics 53 (3): 504-526.

Hutton, A. P., G. S. Miller, and D. J. Skinner. 2003. The role of supplementary statements 
with management earnings forecasts. Journal of Accounting Research 41(5): 867-890.

Gong, G., L. Y. Li, H. Xie. 2009. The association between management earnings forecast errors and accruals. The Accounting Review 84(2): 497-530.

Gotoh, M. 1997. Kaikei to Yosokujouhou. Tokyo: Chuokeizai-sha (in Japanese).

Iwasaki, T., N. Kitagawa, and A. Shuto. 2015. Managerial discretion over initial earnings forecasts. Working paper.

Jennings, R. 1987. Unsystematic security price movements, management earnings forecasts, and revisions in consensus analyst earnings forecasts. Journal of Accounting Research 25(1): 90-110.

Jones, J. J. 1991. Earnings management during import relief investigations. Journal of Accounting Research 29(2): 193-228.

Kasznik, R. 1999. On the association between voluntary disclosure and earnings management. Journal of Accounting Research 37(1): 57-81.

Kato, K., D. J. Skinner, and K. Kunimura. 2009. Management forecasts in Japan: An empirical study of forecasts that are effectively mandated. The Accounting Review 84(5): 1575-1606.

Khan, M. 2008. Are accruals mispriced: evidence from tests of an intertemporal capital asset pricing model. Journal of Accounting and Economics 45(1): 55-77.

Kraft, A., A. Leone, and C. Wasley. 2006. An analysis of the theories and explanations offered for the mispricing of accruals and accrual components. Journal of Accounting Research 44(2): 297-339.

Kubota, K., K. Suda, and H. Takehara. 2010. Dissemination of accruals information, role of 
semi-annual reporting, and analysts' earnings forecasts: Evidence from Japan. Journal of International Financial Management and Accounting 21(2): 120-160.

Kwak, B., B. T. Ro, and I. Suk. 2012. The composition of top management with general counsel and voluntary information disclosure. Journal of Accounting and Economics 54(1): 19-41.

Leippold, M., and H. Lohre. 2012. Data snooping and the global accrual anomaly. Applied Financial Economics 22(7): 509-535.

Lev, B., and S. R. Thiagarajan. 1993. Fundamental information analysis. Journal of Accounting Research 31 (2): 190-215.

Livnat, J., and R. R. Mendenhall. 2006. Comparing the post-earnings announcement drift for surprises calculated from analyst and time series forecasts. Journal of Accounting Research 44(1): 177-205.

Matsumoto, D.A. 2002. Management's incentives to avoid negative earnings surprises. The Accounting Review 77(3): 483-514.

Ng, J., I. Tuna, and R. Verdi. 2013. Management forecast credibility and underreaction to news. Review of Accounting Studies 18(4): 956-986.

Ohlson, J. A. 2001. Earnings, book values, and dividends in equity valuation: An empirical perspective. Contemporary Accounting Research 18(1): 107-120.

Okumura, M. 2003. Consolidated financial information and the rational expectation hypothesis. Accounting (Kaikei) 164(2): 54-68 (written in Japanese).

Ota, K. 2006. Determinants of bias in management earnings forecasts: Empirical evidence from Japan. Gregoriou, G.N., and M. Gaber. International Accounting: Standards, 
Regulations, and Financial Reporting. Elsevier Press, Burlington, MA.

Ota, K. 2010. The value relevance of management forecasts and their impact on analysts' forecasts: Empirical evidence from Japan. ABACUS 46(1): 28-59.

Patell, J. M. 1976. Corporate forecasts of earnings per share and stock price behavior: empirical tests. Journal of Accounting Research 14 (2): 246-276.

Penman, S. H. 1980. An empirical investigation of the voluntary disclosure of corporate earnings forecasts. Journal of Accounting Research. 18(1): 132-160.

Petersen, M. A. 2009. Estimating standard errors in finance panel data sets: Comparing approaches. Review of Financial Studies 22(1): 435-480.

Pincus, M., R. Shivaram, and M. Venkatachalam. 2007. The accruals anomaly: International evidence. The Accounting Review 82(1): 169-203.

Richardson, S. A., I. Tuna, and P. Wysocki. 2010. Accounting anomalies and fundamental analysis: A review of recent research advances. Journal of Accounting and Economics 50(2-3): 410-454.

Richardson, S. A., R. G. Sloan, M. T. Soliman, and I. Tuna. 2005. Accrual reliability, earnings persistence and stock prices. Journal of Accounting and Economics 39(3) 437-485.

Rogers, J. L., and P. C. Stocken. 2005. Credibility of management forecasts. The Accounting Review 80 (4): 1233-1260.

Skinner, D. J. 1994. Why firms voluntarily disclose bad news. Journal of Accounting Research 32(1): 38-60.

Sloan, R. G. 1996. Do stock prices fully reflect information in accruals and cash flows about future earnings? The Accounting Review 71(3): 289-316. 
Waymire, G. 1984. Additional evidence on the information content of management earnings forecasts. Journal of Accounting Research 22(2): 703-718.

Wu, J., 1. Zhang, and X. F. Zhang. 2010. The q-theory approach to understanding the accrual anomaly. Journal of Accounting Research 48(1): 177-222.

Xie, H. 2001. The mispricing of abnormal accruals. The Accounting Review 76(3): 357-373.

$\mathrm{Xu}$, W. 2010. Do management earnings forecasts incorporate information in accruals? Journal of Accounting and Economics 49(3): 227-246.

Zhang, X. F. 2007. Accruals, investment, and the accrual anomaly. The Accounting Review 82(5): 1333-1363. 
Appendix: Definitions of fundamental signals

\section{Signal}

Inventory $\left(I N V_{t-1}\right)$

Accounts receivables $\left(A R_{t-1}\right)$

Capital expenditures $\left(C A P X_{t-1}\right)$

Gross margin $\left(G M_{t-1}\right)$

Selling and administrative expenses $\left(S \& A_{t-}\right.$ 1)

Effective tax rate $\left(E_{T R}\right)$

Change in total accruals $\left(C T A C_{t-1}\right)$

Audit qualification $\left(A Q_{t-1}\right)$

Labor force $\left(L F_{t-1}\right)$

\begin{tabular}{l} 
Measurement \\
\hline$\Delta$ Inventory in year $t-1-\Delta$ Sales in year $t-1 .^{\text {a }}$ The inventory \\
variable is merchandise and finished goods when available; \\
otherwise, it is total inventory.
\end{tabular}

$\Delta$ Accounts receivable in year $t-1-\Delta$ Sales in year $t-1$. The accounts receivable variable is accounts receivable when available; otherwise, it is accounts and notes receivable.

\begin{abstract}
$\Delta$ Industry capital expenditure in year $t-1-\Delta$ Firm capital expenditure in year $t-1$. Industry capital expenditure $=$ aggregating capital expenditure for all firms with the same Nikkei medium classification industry code. Firm capital expenditure $=$ change in gross property, plant, and equipment for a firm.
\end{abstract}

$\Delta$ Sales in year $t-1-\Delta$ Gross margin in year $t-1$.

$\Delta$ Selling and administrative expenses in year $t-1-\Delta$ Sales in year $t-1$.

Average effective tax rate from year $t-5$ to year $t-2$ effective tax rate in year $t-1$. Effective tax rate $=$ income taxes / income before income taxes. Each variable was acquired from the parent-only financial statement.

(total accruals for year $t-1$ minus total accruals for year $t-2$ ) $/$ total assets at the end of year $t-1 .^{\mathrm{b}}$

Dummy variable set to " 0 " if auditor's opinion in year $t-1$ is unqualified and " 1 " if auditor's opinion is qualified or other.

(sales revenue per employee for year $t-2$ - sales revenue per employee for year $t-1)$ / sales revenue per employee for year $t-2$. Sales revenue per employee $=$ sales $/$ the number of employees at year-end.

Note:

${ }^{\text {a }}$ The $\Delta$ operator represents the percentage change in the variable based on a two-year average expectation model, which is the same as that in Lev and Thiagarajan (1993) and Abarbanell and Bushee (1997). For example, $\Delta$ Sales in year $t-1=\left\{\right.$ Sales $\mathrm{t}_{\mathrm{t}-1}-\mathrm{E}($ Sales $\left.\mathrm{t}-1)\right\} /$ $\mathrm{E}\left(\right.$ Sales $\left._{\mathrm{t}-1}\right)$, where $\mathrm{E}\left(\right.$ Sales $\left._{\mathrm{t}-1}\right)=\left(\right.$ Sales $_{\mathrm{t}-2}+$ Sales $\left._{\mathrm{t}-3}\right) / 2$. All other variables with the $\Delta$ operator in this paper are calculated using the same procedure.

${ }^{\mathrm{b}}$ Total accruals are calculated as follows. Total accruals $=$ (change in current assets - change in cash and deposits) $-(\mathrm{change}$ in current liabilities - change in financing items) - (change in allowance for doubtful debts + change in provision for retirement benefits or provision for retirement allowance + change in provision for directors' retirement benefits + change in other long-term provision + depreciation) Financing items $=$ change in short-term loans payable + change in commercial papers + change in current portion of long-term loans payable + change in current portion of straight bonds and convertible bonds. 
Table 1 Sample selection criteria

\section{Criteria}

Firm-years

Firm-years with data on consolidated financial statements during $2003-2009^{1}$

18,957

Less:

Fiscal year does not end in March

$(5,147)$

Changing in accounting month within firm-years necessary for our analyses

Missing data for calculating forecast innovations, forecast errors, and forecast revisions

Missing financial statements and stock data necessary for our analyses

Final sample

Note:

The data of necessary for the study are available from the Nikkei NEEDS Financial QUEST. The industry is based on the Nikkei industry classification code (Nikkei gyousyu chu-bunrui). The financial statements data is acquired from consolidated financial statements.

${ }^{1}$ Excluding financial institutions (banks, securities companies, and insurance companies) and other financial institutions (credit and leasing). 
Table 2 Descriptive statistics

\begin{tabular}{|c|c|c|c|c|c|c|c|c|}
\hline & Mean & Median & Max & Min & SD & Skewness & Kurtosis & $N$ \\
\hline $\operatorname{ERROR}_{t+1}$ & -0.008 & -0.001 & 0.063 & -0.205 & 0.031 & -2.247 & 11.121 & 9,706 \\
\hline REVISION $N_{t+1}$ & -0.008 & 0.000 & 0.062 & -0.196 & 0.029 & -2.323 & 11.359 & 9,706 \\
\hline$F I_{t}$ & 0.009 & 0.003 & 0.234 & -0.103 & 0.031 & 2.685 & 15.292 & 9,706 \\
\hline$D F_{t}$ & 0.007 & 0.001 & 0.239 & -0.114 & 0.034 & 2.103 & 12.133 & 9,706 \\
\hline$N D F_{t}$ & 0.003 & 0.003 & 0.085 & -0.069 & 0.015 & -0.008 & 8.714 & 9,706 \\
\hline$I N V_{t}$ & -0.025 & -0.038 & 4.193 & -1.128 & 0.502 & 3.077 & 22.511 & 9,706 \\
\hline$A R_{t}$ & -0.024 & -0.024 & 0.838 & -0.684 & 0.193 & 0.561 & 6.419 & 9,706 \\
\hline$C A P X_{t}$ & -0.332 & -0.023 & 151.173 & -121.739 & 19.779 & -1.027 & 23.958 & 9,706 \\
\hline$G M_{t}$ & 0.005 & 0.006 & 0.936 & -0.914 & 0.152 & -0.183 & 11.072 & 9,706 \\
\hline$S \& A_{t}$ & -0.016 & -0.013 & 0.372 & -0.517 & 0.112 & -0.312 & 5.295 & 9,706 \\
\hline$E T R_{t}$ & 0.067 & 0.037 & 2.382 & -1.434 & 0.348 & 1.122 & 12.453 & 9,706 \\
\hline$C T A C_{t}$ & 0.000 & 0.000 & 0.300 & -0.309 & 0.071 & -0.085 & 5.770 & 9,706 \\
\hline$A Q_{t}$ & 0.023 & 0.000 & 1.000 & 0.000 & 0.149 & 6.399 & 41.942 & 9,706 \\
\hline$L F_{t}$ & -0.012 & -0.011 & 0.451 & -0.562 & 0.123 & -0.455 & 5.877 & 9,706 \\
\hline BHAR $12_{t+1}$ & 0.016 & -0.006 & 1.700 & -0.884 & 0.290 & 0.959 & 6.496 & 9,706 \\
\hline$B E T A_{t}$ & 0.916 & 0.864 & 2.591 & -0.168 & 0.523 & 0.505 & 3.070 & 9,706 \\
\hline$S I Z E_{t}$ & 10.034 & 9.863 & 14.740 & 6.229 & 1.648 & 0.420 & 2.745 & 9,706 \\
\hline$B M_{t}$ & 1.284 & 1.075 & 5.999 & 0.117 & 0.866 & 1.857 & 7.972 & 9,706 \\
\hline
\end{tabular}

$E_{R R O R}{ }_{t+1}=($ actual net income for year $t+1-$ initial management forecasts for year $t+1) /$ total assets at the end of the year $t-1$.

REVISION $_{t+1}=($ the latest management forecasts for year $t+1-$ initial management forecasts for year $t+1) /$ total assets at the end of year $t-1$.

$F I_{t}=$ (management forecasts for year $t+1$ minus actual net income for year $t$ ) / total assets at the end of year $t-1$.

$D F_{t}=$ forecast innovation $\left(F I_{t}\right)$ minus nondiscretionary forecasts $\left(N D F_{t}\right) . F I_{t}=$ (management forecasts for year $t+1$ minus actual net income for year $t$ ) / total assets at the end of year $t-1 . N D F_{t}=$ nondiscretionary forecasts / total assets at the end of year $t-1$.

$N D F_{t}=$ nondiscretionary forecasts / total assets at the end of year $t-1$.

$I N V_{t}=\Delta$ Inventory in year $t-\Delta$ Sales in year $t$. The Inventory variable is merchandise and finished goods when available, total inventory otherwise.

$A R_{t}=\Delta$ Accounts receivable in year $t-\Delta$ Sales in year $t$. The Accounts receivable variable is accounts receivable when available, accounts and notes receivable otherwise.

$C A P X_{t}=\Delta$ Industry capital expenditure in year $t-\Delta$ Firm capital expenditure in year $t$. Industry capital expenditure $=$ aggregating capital expenditure for all firms with the same the Nikkei medium classification industry code. Firm capital expenditure $=$ change in gross property, plant, and equipment for a firm.

$G M_{t}=\Delta$ Sales in year $t-\Delta$ Gross margin in year $t$.

$S \& A_{t}=\Delta$ Selling and administrative expenses in year $t-\Delta$ Sales in year $t$.

$E T R_{t}=$ average effective tax rate from year $t-4$ to year $t-1-$ effective tax rate in year $t$. Effective tax rate $=$ income taxes $/$ income before income taxes. Each variable are acquired from the parent only financial statement.

$C T A C_{t}=($ total accruals for year $t$ minus total accruals for year $t-1) /$ total assets at the end of year $t$. Total accruals are calculated as follows. Total accruals $=$ (change in current assets - change in cash and deposits $)-($ change in current liabilities - change in financing items) - (change in allowance for doubtful debts + change in provision for retirement benefits or provision for retirement allowance + change in provision for directors' retirement benefits + change in other long-term provision + depreciation $)$. Financing items $=$ change in short-term loans payable + change in commercial papers + change in current portion of long-term loans payable + change in current portion of straight bonds and convertible bonds.

$A Q_{t}=$ dummy variable set to zero if auditor's opinion in year $t$ is unqualified, one if auditor's opinion is qualified or other.

$L F_{t}=$ (sales revenue per employee for year $t-1$ - sales revenue per employee for year $t$ ) / sales revenue per employee for year $t-1$. Sales revenue per employee $=$ sales $/$ the number of employees at year-end.

BHAR $12_{t+1}=$ Size-adjusted return calculated as the buy-and-hold return on the security (including dividends) beginning at the start of the 4 month after fiscal year end and ending at the end of the 3 month the following year less the buy-and-hold return on a sizematched portfolio over the same period.

$B E T A_{t}=$ historical beta which is calculated using monthly returns over the 60 month period ending at the current fiscal year end $t$.

$S I Z E_{t}=$ natural log of market value of equity at the end of year $t$.

$B M_{t}=$ book value of equity at the end of year $t /$ market value of equity at the end of year $t$.

The definitions of all of the fundamental signals except for ETR and CTAC (i.e., INV, AR, CAPX, GM, $S \& A, A Q$, and $L F$ ) come from Lev and Thiagarajan (1993). The $\Delta$ operator represents a percentage change in the percentage change in the variable based on twoyear average expectation model, which is the same as that of prior studies (Lev and Thiagarajan, 1993; Abarbanell and Bushee, 1997). For example, $\Delta$ Sales in year $t=\left\{\right.$ Sales $_{\mathrm{t}}-\mathrm{E}\left(\right.$ Sales $\left.\left._{\mathrm{t}}\right)\right\} / \mathrm{E}\left(\right.$ Sales $\left._{\mathrm{t}}\right)$, where $\mathrm{E}\left(\right.$ Sales $\left._{\mathrm{t}}\right)=\left(\right.$ Sales $_{\mathrm{t}-1}+$ Sales $\left._{\mathrm{t}-2}\right) / 2$. All other variables with $\Delta$ operator in this paper are calculated as the same procedure. 
Table 3 Correlations matrix

\begin{tabular}{|c|c|c|c|c|c|c|c|c|c|c|c|c|c|c|c|c|c|c|}
\hline & (1) & (2) & (3) & (4) & $(5)$ & (6) & (7) & $(8)$ & (9) & $(10)$ & (11) & (12) & (13) & (14) & $(15)$ & $(16)$ & (17) & (18) \\
\hline (1)ERROR $t_{+}$ & & 0.96 & $\begin{array}{c}-0.10 \\
\end{array}$ & -0.11 & 0.04 & 0.00 & 0.01 & -0.02 & -0.09 & -0.09 & 0.05 & -0.01 & 0.02 & -0.09 & 0.36 & -0.05 & 0.10 & -0.07 \\
\hline (2)REVISION $N_{t+1}$ & 0.98 & & -0.09 & -0.11 & 0.04 & 0.01 & 0.02 & -0.02 & -0.08 & -0.09 & 0.05 & -0.01 & 0.02 & -0.09 & 0.35 & -0.05 & 0.10 & -0.08 \\
\hline (3) $F I_{t}$ & -0.18 & -0.17 & & 0.74 & 0.04 & -0.01 & -0.01 & -0.02 & 0.10 & 0.12 & -0.12 & -0.08 & 0.08 & 0.07 & -0.08 & -0.01 & -0.12 & 0.00 \\
\hline (4) $D F_{t}$ & -0.17 & -0.16 & 0.88 & & -0.52 & -0.04 & -0.06 & 0.00 & 0.07 & 0.15 & -0.11 & -0.12 & 0.10 & 0.11 & -0.11 & -0.02 & -0.13 & 0.08 \\
\hline (5) $N D F_{t}$ & 0.01 & 0.01 & 0.07 & -0.38 & & 0.06 & 0.11 & -0.01 & 0.02 & -0.09 & 0.03 & 0.09 & -0.06 & -0.11 & 0.08 & 0.00 & 0.03 & -0.13 \\
\hline (6) $I N V_{t}$ & 0.02 & 0.03 & 0.00 & -0.01 & 0.03 & & 0.16 & -0.01 & -0.01 & 0.10 & 0.01 & 0.07 & 0.00 & 0.08 & -0.01 & -0.06 & 0.01 & -0.04 \\
\hline (7) $A R_{t}$ & 0.03 & 0.03 & -0.03 & -0.05 & 0.05 & 0.13 & & 0.03 & -0.06 & -0.08 & 0.03 & 0.14 & 0.01 & -0.05 & 0.04 & -0.08 & 0.05 & -0.11 \\
\hline (8) $C A P X_{t}$ & -0.01 & -0.01 & -0.01 & 0.00 & -0.01 & 0.00 & 0.01 & & -0.01 & 0.00 & 0.00 & -0.01 & -0.03 & 0.00 & 0.03 & 0.00 & -0.02 & 0.01 \\
\hline (9) $G M_{t}$ & -0.08 & -0.07 & 0.17 & 0.14 & 0.04 & -0.01 & -0.08 & 0.00 & & -0.13 & -0.08 & -0.07 & -0.03 & 0.05 & 0.03 & 0.02 & -0.04 & 0.16 \\
\hline (10) $S \& A_{t}$ & -0.08 & -0.07 & 0.15 & 0.15 & -0.01 & 0.07 & -0.04 & 0.01 & -0.05 & & -0.05 & -0.08 & 0.04 & 0.54 & -0.07 & -0.08 & -0.11 & 0.20 \\
\hline$(11)$ ETR $_{t}$ & 0.05 & 0.05 & -0.07 & -0.08 & 0.03 & 0.00 & 0.00 & 0.01 & -0.08 & -0.05 & & 0.11 & 0.04 & -0.04 & 0.02 & -0.06 & 0.01 & -0.01 \\
\hline (12) $C T A C_{t}$ & 0.01 & 0.01 & -0.11 & -0.14 & 0.10 & 0.05 & 0.13 & -0.01 & -0.10 & -0.09 & 0.07 & & 0.00 & -0.07 & -0.01 & 0.01 & 0.02 & -0.05 \\
\hline (13) $A Q_{t}$ & 0.02 & 0.02 & 0.07 & 0.08 & -0.04 & 0.00 & 0.01 & 0.00 & -0.02 & 0.03 & 0.05 & 0.00 & & 0.01 & -0.08 & -0.04 & -0.02 & 0.05 \\
\hline (14) $L F_{t}$ & -0.06 & -0.06 & 0.05 & 0.07 & -0.05 & 0.06 & 0.02 & 0.01 & 0.07 & 0.56 & -0.04 & -0.06 & 0.00 & & -0.04 & -0.03 & -0.09 & 0.18 \\
\hline (15)BHAR $12_{t+1}$ & 0.30 & 0.29 & -0.07 & -0.09 & 0.06 & 0.00 & 0.02 & -0.01 & 0.01 & -0.05 & 0.02 & -0.01 & -0.06 & -0.04 & & -0.05 & 0.01 & 0.02 \\
\hline (16)BETA & -0.10 & -0.11 & 0.02 & 0.01 & 0.02 & -0.01 & -0.07 & -0.02 & -0.02 & -0.09 & -0.05 & 0.01 & -0.04 & -0.05 & 0.00 & & 0.14 & -0.16 \\
\hline (17)SIZE & 0.11 & 0.10 & -0.18 & -0.17 & 0.01 & 0.00 & 0.04 & -0.01 & -0.05 & -0.09 & 0.01 & 0.02 & -0.01 & -0.07 & 0.01 & 0.13 & & -0.54 \\
\hline (18) $B M_{t}$ & -0.05 & -0.05 & 0.07 & 0.09 & -0.07 & -0.05 & -0.11 & 0.02 & 0.14 & 0.18 & -0.02 & -0.04 & 0.05 & 0.17 & 0.01 & -0.12 & -0.51 & \\
\hline
\end{tabular}

Note:

Spearman (Pearson) correlations are above (below) the diagonal.

$E R_{R O R}{ }_{t+1}=$ (actual net income for year $t+1$ - initial management forecasts for year $\left.t+1\right) /$ total assets at the end of the year $t-1$.

$\operatorname{REVISION}_{t+1}=($ the latest management forecasts for year $t+1$ - initial management forecasts for year $t+1) /$ total assets at the end of year $t-1$.

$F I_{t}=$ (management forecasts for year $t+1$ minus actual net income for year $\left.t\right) /$ total assets at the end of year $t-1$.

$D F_{t}=$ forecast innovation $\left(F I_{t}\right)$ minus nondiscretionary forecasts $\left(N D F_{t}\right)$. $F I_{t}=($ management forecasts for year $t+1$ minus actual net income for year $t) /$ total assets at the end of year $t-1$. $N D F_{t}=$ nondiscretionary forecasts / total assets at the end of year $t-1$

$N D F_{t}=$ nondiscretionary forecasts $/$ total assets at the end of year $t-1$

$I N V_{t}=\Delta$ Inventory in year $t-\Delta$ Sales in year $t$. The Inventory variable is merchandise and finished goods when available, total inventory otherwise.

$A R_{t}=\Delta$ Accounts receivable in year $t-\Delta$ Sales in year $t$. The Accounts receivable variable is accounts receivable when available, accounts and notes receivable otherwise.

$C A P X_{t}=\Delta$ Industry capital expenditure in year $t-\Delta$ Firm capital expenditure in year $t$. Industry capital expenditure $=$ aggregating capital expenditure for all firms with the same the Nikkei medium classification industry code. Firm capital expenditure = change in gross property, plant, and equipment for a firm.

$G M_{t}=\Delta$ Sales in year $t-\Delta$ Gross margin in year $t$

$S \& A_{t}=\Delta$ Selling and administrative expenses in year $t-\Delta$ Sales in year $t$.

$E T R_{t}=$ average effective tax rate from year $t-4$ to year $t-1-$ effective tax rate in year $t$. Effective tax rate $=$ income taxes $/$ income before income taxes. Each variable are acquired from the parent only financial statement.

$C T A C_{t}=$ (total accruals for year $t$ minus total accruals for year $\left.t-1\right) /$ total assets at the end of year $t$. Total accruals are calculated as follows. Total accruals $=($ change in current assets change in cash and deposits) - (change in current liabilities - change in financing items) - (change in allowance for doubtful debts + change in provision for retirement benefits or provision for retirement allowance + change in provision for directors' retirement benefits + change in other lon $\alpha$-term provision + depreciation). Financing items $=$ change in short-term loans payable + change in commercial papers + change in current portion of long-term loans payable + change in current portion of straight bonds and convertible bonds.

$A Q_{t}=$ dummy variable set to zero if auditor's opinion in year $t$ is unqualified, one if auditor's opinion is qualified or other.

$L F_{t}=($ sales revenue per employee for year $t-1$ - sales revenue per employee for year $t) /$ sales revenue per employee for year $t-1$. Sales revenue per employee $=$ sales $/$ the number of employees at year-end.

$B H A R I 2_{t+1}=$ Size-adjusted return calculated as the buy-and-hold return on the security (including dividends) beginning at the start of the 4 month after fiscal year end and ending at the end of the 3 month the following year less the buy-and-hold return on a size-matched portfolio over the same period.

$B E T A_{t}=$ historical beta which is calculated using monthly returns over the 60 month period ending at the current fiscal year end $t$.

$S I Z E_{t}=$ natural log of market value of equity at the end of year $t$. 
$B M_{t}=$ book value of equity at the end of year $t /$ market value of equity at the end of year $t$.

The definitions of all of the fundamental signals except for $E T R$ and $C T A C$ (i.e., $I N V, A R, C A P X, G M, S \& A, A Q$, and $L F$ ) come from Lev and Thiagarajan (1993). The $\triangle$ operator represents a percentage change in the percentage change in the variable based on two-year average expectation model, which is the same as that of prior studies (Lev and Thiagarajan, 1993 ; Abarbanell and Bushee, 1997). For example, $\Delta$ Sales in year $t=\left\{\right.$ Sales $_{\mathrm{t}}-\mathrm{E}\left(\right.$ Sales $\left.\left._{\mathrm{t}}\right)\right\} / \mathrm{E}\left(\right.$ Sales $\left._{\mathrm{t}}\right)$, where $\mathrm{E}\left(\right.$ Sales $\left._{\mathrm{t}}\right)=\left(\right.$ Sales $_{\mathrm{t}-1}+$ Sales $\left._{\mathrm{t}-2}\right) / 2$. All other variables with $\Delta$ operator in this paper are calculated as the same procedure.

Bold indicates statistically significant at less than 0.1 level of significance using a two-tailed $t$-test. 
Table 4 Management forecast errors and forecast revisions for $D F$ portfolio

\begin{tabular}{|c|c|c|c|c|}
\hline \multirow{3}{*}{$\begin{array}{l}\text { Portfolio } \\
\text { Ranking }\end{array}$} & \multicolumn{4}{|c|}{ Ranked by $D F_{t}$} \\
\hline & \multicolumn{2}{|c|}{ ERROR $_{t+1}$} & \multicolumn{2}{|c|}{ REVISION $_{t+1}$} \\
\hline & Mean & Median & Mean & Median \\
\hline Lowest (-) & -0.007 & 0.000 & -0.007 & 0.000 \\
\hline 2 & -0.005 & 0.000 & -0.006 & 0.000 \\
\hline 3 & -0.004 & 0.000 & -0.005 & 0.000 \\
\hline 4 & -0.005 & 0.000 & -0.006 & 0.000 \\
\hline 5 & -0.004 & 0.000 & -0.005 & 0.000 \\
\hline 6 & -0.007 & -0.001 & -0.007 & 0.000 \\
\hline 7 & -0.006 & -0.002 & -0.006 & 0.000 \\
\hline 8 & -0.007 & -0.002 & -0.008 & 0.000 \\
\hline 9 & -0.012 & -0.004 & -0.012 & -0.003 \\
\hline Highest (+) & -0.023 & -0.007 & -0.022 & -0.006 \\
\hline Highest - Lowest & $-0.016^{* * *}$ & $-0.007 * * *$ & $-0.015 * * *$ & $-0.006 * * *$ \\
\hline$t$-value/z-value & $(-8.318)$ & $(-7.923)$ & $(-8.011)$ & $(-7.579)$ \\
\hline$N$ & 9,706 & 9,706 & 9,706 & 9,706 \\
\hline
\end{tabular}

$D F_{t}=$ forecast innovation $\left(F I_{t}\right)$ minus nondiscretionary forecasts $\left(N D F_{t}\right) . F I_{t}=($ management forecasts for year $t+1$ minus actual net income for year $t) /$ total assets at the end of year $t-1 . N D F_{t}=$ nondiscretionary forecasts / total assets at the end of year $t-1$.

$E_{R R O R}{ }_{t+1}=($ actual net income for year $t+1-$ initial management forecasts for year $t+1) /$ total assets at the end of the year $t-1$.

REVISION $_{t+1}=($ the latest management forecasts for year $t+1-$ initial management forecasts for year $t+1) /$ total assets at the end of year $t-1$.

*** Statistically significant at the 0.01 level of significance using a two-tailed $t$-test 
Table 5 Regressions of management forecast errors on discretionary forecasts

\begin{tabular}{|c|c|c|c|}
\hline \multirow{3}{*}{$\begin{array}{l}\text { Independent } \\
\text { variable }\end{array}$} & \multirow{3}{*}{$\begin{array}{c}\text { Expected } \\
\text { sign }\end{array}$} & \multicolumn{2}{|c|}{ Dependent variable $=E R R O R_{t+1}$} \\
\hline & & \multicolumn{2}{|c|}{ Model (4) } \\
\hline & & Coefficient & $t$-value \\
\hline Constant & $?$ & $-0.020 * * *$ & $(-3.679)$ \\
\hline$D F_{t}$ & - & $-0.141 * * *$ & $(-4.684)$ \\
\hline$N D F_{t}$ & $?$ & $-0.093 * *$ & $(-1.998)$ \\
\hline$I N V_{t}$ & - & 0.002 & $(0.484)$ \\
\hline$A R_{t}$ & - & 0.002 & $(0.286)$ \\
\hline$C A P X_{t}$ & - & $0.000 *$ & $(-1.906)$ \\
\hline$G M_{t}$ & - & -0.012 & $(-1.061)$ \\
\hline$S \& A_{t}$ & - & -0.014 & $(-1.200)$ \\
\hline$E T R_{t}$ & - & 0.002 & $(1.619)$ \\
\hline$C T A C_{t}$ & - & $-0.011 * *$ & $(-2.546)$ \\
\hline$A Q_{t}$ & - & 0.006 & $(1.181)$ \\
\hline$L F_{t}$ & - & -0.006 & $(-0.870)$ \\
\hline$B E T A_{t}$ & + & -0.007 & $(-1.323)$ \\
\hline$S I Z E_{t}$ & - & $0.002 * * *$ & $(4.746)$ \\
\hline$B M_{t}$ & + & 0.001 & $(0.427)$ \\
\hline Adj. $R^{2}$ & & 0.060 & \\
\hline$N$ & & 9,706 & \\
\hline
\end{tabular}

$E_{R R O R}{ }_{t+1}=($ actual net income for year $t+1$ - initial management forecasts for year $t+1) /$ total assets at the end of the year $t-1$.

$D F_{t}=$ forecast innovation $\left(F I_{t}\right)$ minus nondiscretionary forecasts $\left(N D F_{t}\right) . F I_{t}=$ (management forecasts for year $t+1$ minus actual net income for year $t$ ) / total assets at the end of year $t-1 . N D F_{t}=$ nondiscretionary forecasts / total assets at the end of year $t-1$.

$N D F_{t}=$ nondiscretionary forecasts / total assets at the end of year $t-1$.

$I N V_{t}=\Delta$ Inventory in year $t-\Delta$ Sales in year $t$. The Inventory variable is merchandise and finished goods when available, total inventory otherwise.

$A R_{t}=\Delta$ Accounts receivable in year $t-\Delta$ Sales in year $t$. The Accounts receivable variable is accounts receivable when available, accounts and notes receivable otherwise.

$C A P X_{t}=\Delta$ Industry capital expenditure in year $t-\Delta$ Firm capital expenditure in year $t$. Industry capital expenditure $=$ aggregating capital expenditure for all firms with the same the Nikkei medium classification industry code. Firm capital expenditure $=$ change in gross property, plant, and equipment for a firm.

$G M_{t}=\Delta$ Sales in year $t-\Delta$ Gross margin in year $t$.

$S \& A_{t}=\Delta$ Selling and administrative expenses in year $t-\Delta$ Sales in year $t$.

$E T R_{t}=$ average effective tax rate from year $t-4$ to year $t-1-$ effective tax rate in year $t$. Effective tax rate $=$ income taxes $/$ income before income taxes. Each variable are acquired from the parent only financial statement.

$C T A C_{t}=($ total accruals for year $t$ minus total accruals for year $t-1) /$ total assets at the end of year $t$. Total accruals are calculated as follows. Total accruals $=$ (change in current assets - change in cash and deposits $)-($ change in current liabilities - change in financing items) - (change in allowance for doubtful debts + change in provision for retirement benefits or provision for retirement allowance + change in provision for directors' retirement benefits + change in other long-term provision + depreciation). Financing items $=$ change in short-term loans payable + change in commercial papers + change in current portion of long-term loans payable + change in current portion of straight bonds and convertible bonds.

$A Q_{t}=$ dummy variable set to zero if auditor's opinion in year $t$ is unqualified, one if auditor's opinion is qualified or other.

$L F_{t}=$ (sales revenue per employee for year $t-1$ - sales revenue per employee for year $t$ ) / sales revenue per employee for year $t-1$. Sales revenue per employee $=$ sales $/$ the number of employees at year-end.

$B H A R 12_{t+1}=$ Size-adjusted return calculated as the buy-and-hold return on the security (including dividends) beginning at the start of the 4 month after fiscal year end and ending at the end of the 3 month the following year less the buy-and-hold return on a sizematched portfolio over the same period.

$B E T A_{t}=$ historical beta which is calculated using monthly returns over the 60 month period ending at the current fiscal year end $t$. $S I Z E_{t}=$ natural log of market value of equity at the end of year $t$.

$B M_{t}=$ book value of equity at the end of year $t /$ market value of equity at the end of year $t$.

The definitions of all of the fundamental signals except for ETR and CTAC (i.e., INV, $A R, C A P X, G M, S \& A, A Q$, and $L F$ ) come from Lev and Thiagarajan (1993). The $\Delta$ operator represents a percentage change in the percentage change in the variable based on twoyear average expectation model, which is the same as that of prior studies (Lev and Thiagarajan, 1993; Abarbanell and Bushee, 1997). For example, $\Delta$ Sales in year $t=\left\{\right.$ Sales $_{\mathrm{t}}-\mathrm{E}\left(\right.$ Sales $\left.\left._{\mathrm{t}}\right)\right\} / \mathrm{E}\left(\right.$ Sales $\left._{\mathrm{t}}\right)$, where $\mathrm{E}\left(\right.$ Sales $\left._{\mathrm{t}}\right)=\left(\right.$ Sales $_{\mathrm{t}-1}+$ Sales $\left._{\mathrm{t}-2}\right) / 2$. All other variables with $\Delta$ operator in this paper are calculated as the same procedure.

All variables are winsorized at one percent by year.

$t$-statistics are corrected for heteroskedasticity, and cross-sectional and time-series correlation using a two-way cluster at the firm and 
year level proposed by Petersen (2009).

$* * *$ Statistically significant at the 0.01 level of significance using a two-tailed $t$-test

** Statistically significant at the 0.05 level of significance using a two-tailed $t$-test

* Statistically significant at the 0.1 level. of significance using a two-tailed $t$-test 
Table 6 Regressions of management forecast revisions on discretionary forecasts

\begin{tabular}{|c|c|c|c|}
\hline \multirow{3}{*}{$\begin{array}{c}\text { Independent } \\
\text { variable }\end{array}$} & \multirow{3}{*}{$\begin{array}{l}\text { Expected } \\
\text { sign }\end{array}$} & \multicolumn{2}{|c|}{ Dependent variable $=$ REVISION $N_{t+1}$} \\
\hline & & \multicolumn{2}{|c|}{ Model (5) } \\
\hline & & Coefficient & $t$-value \\
\hline Constant & ? & $-0.019 * * *$ & $(-3.469)$ \\
\hline$D F_{t}$ & - & $-0.129 * * *$ & $(-5.236)$ \\
\hline$N D F_{t}$ & ? & $-0.083^{*}$ & $(-1.895)$ \\
\hline$I N V_{t}$ & - & 0.002 & $(0.546)$ \\
\hline$A R_{t}$ & - & 0.002 & $(0.360)$ \\
\hline$C A P X_{t}$ & - & -0.000 & $(-1.510)$ \\
\hline$G M_{t}$ & - & -0.010 & $(-1.004)$ \\
\hline$S \& A_{t}$ & - & -0.011 & $(-1.005)$ \\
\hline$E T R_{t}$ & - & 0.002 & $(1.381)$ \\
\hline$C T A C_{t}$ & - & $-0.010 * *$ & $(-2.468)$ \\
\hline$A Q_{t}$ & - & 0.005 & (1.234) \\
\hline$L F_{t}$ & - & -0.008 & $(-1.178)$ \\
\hline$B E T A_{t}$ & + & -0.007 & $(-1.366)$ \\
\hline$S I Z E_{t}$ & - & $0.002 * * *$ & (4.333) \\
\hline$B M_{t}$ & + & 0.001 & $(0.421)$ \\
\hline Adj. $R^{2}$ & & 0.056 & \\
\hline$N$ & & 9,706 & \\
\hline
\end{tabular}

REVISION $_{t+1}=($ the latest management forecasts for year $t+1-$ initial management forecasts for year $t+1) /$ total assets at the end of year $t-1$.

$D F_{t}=$ forecast innovation $\left(F I_{t}\right)$ minus nondiscretionary forecasts $\left(N D F_{t}\right) . F I_{t}=$ (management forecasts for year $t+1$ minus actual net income for year $t) /$ total assets at the end of year $t-1 . N D F_{t}=$ nondiscretionary forecasts / total assets at the end of year $t-1$.

$N D F_{t}=$ nondiscretionary forecasts / total assets at the end of year $t-1$.

$I N V_{t}=\Delta$ Inventory in year $t-\Delta$ Sales in year $t$. The Inventory variable is merchandise and finished goods when available, total inventory otherwise.

$A R_{t}=\Delta$ Accounts receivable in year $t-\Delta$ Sales in year $t$. The Accounts receivable variable is accounts receivable when available, accounts and notes receivable otherwise.

$C A P X_{t}=\Delta$ Industry capital expenditure in year $t-\Delta$ Firm capital expenditure in year $t$. Industry capital expenditure $=$ aggregating capital expenditure for all firms with the same the Nikkei medium classification industry code. Firm capital expenditure $=$ change in gross property, plant, and equipment for a firm.

$G M_{t}=\Delta$ Sales in year $t-\Delta$ Gross margin in year $t$.

$S \& A_{t}=\Delta$ Selling and administrative expenses in year $t-\Delta$ Sales in year $t$.

$E T R_{t}=$ average effective tax rate from year $t-4$ to year $t-1-$ effective tax rate in year $t$. Effective tax rate $=$ income taxes $/$ income before income taxes. Each variable are acquired from the parent only financial statement.

$C T A C_{t}=($ total accruals for year $t$ minus total accruals for year $t-1) /$ total assets at the end of year $t$. Total accruals are calculated as follows. Total accruals $=($ change in current assets - change in cash and deposits $)-($ change in current liabilities - change in financing items) - (change in allowance for doubtful debts + change in provision for retirement benefits or provision for retirement allowance + change in provision for directors' retirement benefits + change in other long-term provision + depreciation). Financing items $=$ change in short-term loans payable + change in commercial papers + change in current portion of long-term loans payable + change in current portion of straight bonds and convertible bonds.

$A Q_{t}=$ dummy variable set to zero if auditor's opinion in year $t$ is unqualified, one if auditor's opinion is qualified or other.

$L F_{t}=$ (sales revenue per employee for year $t-1$ - sales revenue per employee for year $t$ )/ sales revenue per employee for year $t-1$. Sales revenue per employee $=$ sales $/$ the number of employees at year-end.

$B E T A_{t}=$ historical beta which is calculated using monthly returns over the 60 month period ending at the current fiscal year end $t$.

$S I Z E_{t}=$ natural log of market value of equity at the end of year $t$.

$B M_{t}=$ book value of equity at the end of year $t /$ market value of equity at the end of year $t$.

The definitions of all of the fundamental signals except for ETR and CTAC (i.e., INV, $A R, C A P X, G M, S \& A, A Q$, and $L F$ ) come from Lev and Thiagarajan (1993). The $\Delta$ operator represents a percentage change in the percentage change in the variable based on twoyear average expectation model, which is the same as that of prior studies (Lev and Thiagarajan, 1993; Abarbanell and Bushee, 1997). For example, $\Delta$ Sales in year $t=\left\{\right.$ Sales $_{\mathrm{t}}-\mathrm{E}\left(\right.$ Sales $\left.\left._{\mathrm{t}}\right)\right\} / \mathrm{E}\left(\right.$ Sales $\left._{\mathrm{t}}\right)$, where $\mathrm{E}\left(\right.$ Sales $\left._{\mathrm{t}}\right)=\left(\right.$ Sales $_{\mathrm{t}-1}+$ Sales $\left._{\mathrm{t}-2}\right) / 2$. All other variables with $\Delta$ operator in this paper are calculated as the same procedure.

All variables are winsorized at one percent by year.

$t$-statistics are corrected for heteroskedasticity, and cross-sectional and time-series correlation using a two-way cluster at the firm and year level proposed by Petersen (2009).

*** Statistically significant at the 0.01 level of significance using a two-tailed $t$-test 
** Statistically significant at the 0.05 level of significance using a two-tailed $t$-test * Statistically significant at the 0.1 level. of significance using a two-tailed $t$-test 
Table 7 Size-adjusted abnormal returns for $D F$ and $N D F$ portfolio in three years after portfolio formation

\begin{tabular}{|c|c|c|c|c|c|c|c|c|}
\hline \multirow{2}{*}{$\begin{array}{l}\text { Portfolio } \\
\text { Ranking }\end{array}$} & \multicolumn{4}{|c|}{ Ranked by $D F_{t}$} & \multicolumn{4}{|c|}{ Ranked by $N D F_{t}$} \\
\hline & 6 months & 12 months & 24 months & 36 months & 6 months & 12 months & 24 months & 36 months \\
\hline Lowest (-) & 0.021 & 0.041 & 0.073 & 0.085 & -0.001 & 0.000 & 0.013 & 0.018 \\
\hline 2 & 0.011 & 0.029 & 0.060 & 0.072 & 0.018 & 0.011 & 0.058 & 0.080 \\
\hline 3 & 0.018 & 0.037 & 0.069 & 0.095 & 0.016 & 0.017 & 0.052 & 0.082 \\
\hline 4 & 0.026 & 0.026 & 0.043 & 0.056 & 0.018 & 0.010 & 0.051 & 0.062 \\
\hline 5 & 0.024 & 0.020 & 0.063 & 0.093 & 0.018 & 0.023 & 0.064 & 0.071 \\
\hline 6 & 0.014 & 0.012 & 0.043 & 0.073 & 0.005 & 0.018 & 0.055 & 0.087 \\
\hline 7 & 0.021 & 0.009 & 0.047 & 0.073 & 0.012 & 0.020 & 0.061 & 0.066 \\
\hline 8 & 0.013 & 0.000 & 0.031 & 0.046 & 0.008 & 0.010 & 0.028 & 0.057 \\
\hline 9 & 0.004 & 0.000 & 0.033 & 0.046 & 0.019 & 0.031 & 0.048 & 0.067 \\
\hline Highest (+) & -0.019 & -0.014 & -0.006 & -0.019 & 0.021 & 0.020 & 0.026 & 0.033 \\
\hline Hedge & $0.041 * * *$ & $0.055 * * *$ & $0.080 * * *$ & $0.103 * * *$ & $-0.022 * *$ & -0.020 & -0.014 & -0.015 \\
\hline ( $t$-value) & $(3.754)$ & $(3.648)$ & (3.919) & $(4.104)$ & $(-2.032)$ & $(-1.339)$ & $(-0.680)$ & $(-0.608)$ \\
\hline$N$ & 9,706 & 9,706 & 9,706 & 9,706 & 9,706 & 9,706 & 9,706 & 9,706 \\
\hline $\begin{array}{l}\text { Note: } \\
\qquad F_{t}=\text { fore } \\
\text { income } \\
N D F_{t}=\text { non } \\
\text { Size-adjust } \\
\text { the } 4 \mathrm{~m} \\
\text { return o } \\
* * * \text { Statist } \\
* * \text { Statistic } \\
* \text { Statistica }\end{array}$ & $\begin{array}{l}\text { nnovation ( } \\
\text { ear } t \text { ) / total a } \\
\text { etionary for } \\
\text { normal retur } \\
\text { after fiscal y } \\
\text { ize-matched } \\
\text { significant } \\
\text { ignificant at } \\
\text { gnificant at } t\end{array}$ & $\begin{array}{l}\text { minus non } \\
\text { ets at the en } \\
\text { ists / total as } \\
\text { are calculat } \\
\text { r end } t \text { and e } \\
\text { rtfolio over } \\
\text { he } 0.01 \text { leve } \\
\text { e } 0.05 \text { level } \\
0.1 \text { level of }\end{array}$ & $\begin{array}{l}\text { iscretionary } \\
\text { of year } t-1 . N \\
\text { ets at the end } \\
d \text { as the buy-a } \\
\text { ding at the en } \\
\text { le same perio } \\
\text { of significanc } \\
\text { f significance } \\
\text { ignificance u }\end{array}$ & $\begin{array}{l}\text { ecasts ( } N D F \\
F_{t}=\text { nondisc } \\
\text { year } t-1 \text {. } \\
\text { l-hold return } \\
\text { of the indica } \\
\text { using a two- } \\
\text { sing a two-ta }\end{array}$ & $\begin{array}{l}I_{t}=\text { (managem } \\
\text { nary forecasts } \\
\text { he security (in } \\
\text { ear (i.e., year } t \\
\text { d } t \text {-test } \\
t \text {-test } \\
\text { est }\end{array}$ & $\begin{array}{l}\text { nt forecasts } \\
\text { total assets at } \\
\text { luding divider } \\
-t^{+}+2 \text {, and } t^{+}\end{array}$ & $\begin{array}{l}\text { year } t+1 \mathrm{mi} \\
\text { he end of year } \\
\text { ) beginning }\end{array}$ & $\begin{array}{l}\text { us actual net } \\
\text { the start of } \\
\text { nd-hold }\end{array}$ \\
\hline
\end{tabular}


Table 8 Regressions of size-adjusted abnormal returns on discretionary forecasts

\begin{tabular}{|c|c|c|c|}
\hline \multirow{3}{*}{$\begin{array}{c}\text { Independent } \\
\text { variable }\end{array}$} & \multirow{3}{*}{$\begin{array}{l}\text { Expected } \\
\text { sign }\end{array}$} & \multicolumn{2}{|c|}{ Dependent variable $=$ BHAR12 ${ }_{t+1}$} \\
\hline & & \multicolumn{2}{|c|}{ Model (6) } \\
\hline & & Coefficient & $t$-value \\
\hline Constant & $?$ & -0.013 & $(-0.127)$ \\
\hline$D F_{t}$ & - & $-0.631 * * *$ & $(-4.728)$ \\
\hline$N D F_{t}$ & $?$ & 0.615 & $(0.979)$ \\
\hline$I N V_{t}$ & - & -0.000 & $(-0.023)$ \\
\hline$A R_{t}$ & - & 0.034 & (1.497) \\
\hline$C A P X_{t}$ & - & -0.000 & $(-0.857)$ \\
\hline$G M_{t}$ & - & 0.031 & $(0.535)$ \\
\hline$S \& A_{t}$ & - & -0.083 & $(-0.879)$ \\
\hline$E T R_{t}$ & - & 0.010 & $(1.620)$ \\
\hline$C T A C_{t}$ & - & -0.108 & $(-1.584)$ \\
\hline$A Q_{t}$ & - & $-0.103 * * *$ & $(-4.363)$ \\
\hline$L F_{t}$ & - & -0.055 & $(-1.142)$ \\
\hline$B E T A_{t}$ & + & 0.001 & $(0.022)$ \\
\hline$S I Z E_{t}$ & - & 0.002 & $(0.261)$ \\
\hline$B M_{t}$ & + & $0.011 * *$ & $(2.395)$ \\
\hline Adj. $R^{2}$ & & 0.016 & \\
\hline$N$ & & 9,706 & \\
\hline
\end{tabular}

BHAR $12_{t+1}=$ Size-adjusted return calculated as the buy-and-hold return on the security (including dividends) beginning at the start of the 4 month after fiscal year end and ending at the end of the 3 month the following year less the buy-and-hold return on a sizematched portfolio over the same period.

$D F_{t}=$ forecast innovation $\left(F I_{t}\right)$ minus nondiscretionary forecasts $\left(N D F_{t}\right) . F I_{t}=$ (management forecasts for year $t+1$ minus actual net income for year $t$ ) / total assets at the end of year $t-1 . N D F_{t}=$ nondiscretionary forecasts / total assets at the end of year $t-1$.

$N D F_{t}=$ nondiscretionary forecasts / total assets at the end of year $t-1$.

$I N V_{t}=\Delta$ Inventory in year $t-\Delta$ Sales in year $t$. The Inventory variable is merchandise and finished goods when available, total inventory otherwise.

$A R_{t}=\Delta$ Accounts receivable in year $t-\Delta$ Sales in year $t$. The Accounts receivable variable is accounts receivable when available, accounts and notes receivable otherwise.

$C A P X_{t}=\Delta$ Industry capital expenditure in year $t-\Delta$ Firm capital expenditure in year $t$. Industry capital expenditure $=$ aggregating capital expenditure for all firms with the same the Nikkei medium classification industry code. Firm capital expenditure $=$ change in gross property, plant, and equipment for a firm.

$G M_{t}=\Delta$ Sales in year $t-\Delta$ Gross margin in year $t$.

$S \& A_{t}=\Delta$ Selling and administrative expenses in year $t-\Delta$ Sales in year $t$.

$E T R_{t}=$ average effective tax rate from year $t-4$ to year $t-1-$ effective tax rate in year $t$. Effective tax rate $=$ income taxes $/$ income before income taxes. Each variable are acquired from the parent only financial statement.

$C T A C_{t}=($ total accruals for year $t$ minus total accruals for year $t-1) /$ total assets at the end of year $t$. Total accruals are calculated as follows. Total accruals $=($ change in current assets - change in cash and deposits $)-($ change in current liabilities - change in financing items) - (change in allowance for doubtful debts + change in provision for retirement benefits or provision for retirement allowance + change in provision for directors' retirement benefits + change in other long-term provision + depreciation). Financing items $=$ change in short-term loans payable + change in commercial papers + change in current portion of long-term loans payable + change in current portion of straight bonds and convertible bonds.

$A Q_{t}=$ dummy variable set to zero if auditor's opinion in year $t$ is unqualified, one if auditor's opinion is qualified or other.

$L F_{t}=$ (sales revenue per employee for year $t-1$ - sales revenue per employee for year $t$ ) / sales revenue per employee for year $t-1$. Sales revenue per employee $=$ sales $/$ the number of employees at year-end.

$B E T A_{t}=$ historical beta which is calculated using monthly returns over the 60 month period ending at the current fiscal year end $t$.

$S I Z E_{t}=$ natural log of market value of equity at the end of year $t$.

$B M_{t}=$ book value of equity at the end of year $t /$ market value of equity at the end of year $t$.

The definitions of all of the fundamental signals except for ETR and CTAC (i.e., INV, AR, CAPX, GM, $S \& A, A Q$, and $L F$ ) come from

Lev and Thiagarajan (1993). The $\Delta$ operator represents a percentage change in the percentage change in the variable based on twoyear average expectation model, which is the same as that of prior studies (Lev and Thiagarajan, 1993; Abarbanell and Bushee, 1997). For example, $\Delta$ Sales in year $t=\left\{\right.$ Sales $_{\mathrm{t}}-\mathrm{E}\left(\right.$ Sales $\left.\left._{\mathrm{t}}\right)\right\} / \mathrm{E}\left(\right.$ Sales $\left._{\mathrm{t}}\right)$, where $\mathrm{E}\left(\right.$ Sales $\left._{\mathrm{t}}\right)=\left(\right.$ Sales $_{\mathrm{t}-1}+$ Sales $\left._{\mathrm{t}-2}\right) / 2$. All other variables with $\Delta$ operator in this paper are calculated as the same procedure.

All variables are winsorized at one percent by year.

$t$-statistics are corrected for heteroskedasticity, and cross-sectional and time-series correlation using a two-way cluster at the firm and year level proposed by Petersen (2009). 
*** Statistically significant at the 0.01 level of significance using a two-tailed $t$-test 
Table 9 Regressions of size-adjusted abnormal returns on discretionary forecasts controlling accruals and discretionary accruals

\begin{tabular}{|c|c|c|c|c|c|}
\hline \multirow{3}{*}{$\begin{array}{c}\text { Independent } \\
\text { variable }\end{array}$} & \multirow{3}{*}{$\begin{array}{c}\text { Expected } \\
\text { sign }\end{array}$} & \multicolumn{4}{|c|}{ Dependent variable $=B H A R 12_{t+1}$} \\
\hline & & \multicolumn{2}{|c|}{ Model (7) } & \multicolumn{2}{|c|}{ Model (8) } \\
\hline & & Coefficient & $t$-value & Coefficient & $t$-value \\
\hline Constant & ? & -0.022 & $(-0.208)$ & -0.019 & $(-0.171)$ \\
\hline$D F_{t}$ & - & $-0.706 * * *$ & $(-4.747)$ & $-0.666 * * *$ & $(-4.322)$ \\
\hline$N D F_{t}$ & ? & 0.405 & $(0.656)$ & 0.487 & $(0.842)$ \\
\hline$T A C_{t}$ & - & $-0.435^{* * *}$ & $(-2.818)$ & & \\
\hline$D A C_{t}$ & - & & & $-0.333^{* * *}$ & $(-3.557)$ \\
\hline$I N V_{t}$ & - & 0.002 & $(0.195)$ & 0.000 & $(0.014)$ \\
\hline$A R_{t}$ & - & $0.048 * *$ & $(2.299)$ & $0.045 *$ & $(1.894)$ \\
\hline$C A P X_{t}$ & - & -0.000 & $(-0.848)$ & -0.000 & $(-0.791)$ \\
\hline$G M_{t}$ & - & 0.040 & $(0.713)$ & 0.034 & $(0.584)$ \\
\hline$S \& A_{t}$ & - & -0.087 & $(-0.918)$ & -0.083 & $(-0.864)$ \\
\hline$E T R_{t}$ & - & 0.010 & $(1.588)$ & $0.010 *$ & $(1.654)$ \\
\hline$C T A C_{t}$ & - & $0.102 *$ & $(1.684)$ & -0.023 & $(-0.474)$ \\
\hline$A Q_{t}$ & - & $-0.109 * * *$ & $(-4.501)$ & $-0.118 * * *$ & $(-5.060)$ \\
\hline$L F_{t}$ & - & -0.062 & $(-1.278)$ & -0.059 & $(-1.304)$ \\
\hline$B E T A_{t}$ & + & 0.002 & $(0.065)$ & 0.001 & $(0.049)$ \\
\hline$S I Z E_{t}$ & - & 0.001 & $(0.202)$ & 0.002 & $(0.301)$ \\
\hline$B M_{t}$ & + & $0.012 * *$ & (2.479) & $0.013 * *$ & $(2.426)$ \\
\hline Adj. $R^{2}$ & & 0.019 & & 0.019 & \\
\hline$N$ & & 9,706 & & 9,706 & \\
\hline
\end{tabular}

$B H A R 12_{t+1}=$ Size-adjusted return calculated as the buy-and-hold return on the security (including dividends) beginning at the start of the 4 month after fiscal year end and ending at the end of the 3 month the following year less the buy-and-hold return on a sizematched portfolio over the same period.

$D F_{t}=$ forecast innovation $\left(F I_{t}\right)$ minus nondiscretionary forecasts $\left(N D F_{t}\right) . F I_{t}=$ (management forecasts for year $t+1$ minus actual net income for year $t$ ) / total assets at the end of year $t-1 . N D F_{t}=$ nondiscretionary forecasts / total assets at the end of year $t-1$.

$N D F_{t}=$ nondiscretionary forecasts / total assets at the end of year $t-1$.

$T A C_{t}=$ total accruals for year $t /$ total assets at the end of year $t-1$. Total accruals are calculated as follows. Total accruals $=($ change in current assets - change in cash and deposits) - (change in current liabilities - change in financing items) - (change in allowance for doubtful debts + change in provision for retirement benefits or provision for retirement allowance + change in provision for directors' retirement benefits + change in other long-term provision + depreciation). Financing items $=$ change in short-term loans payable + change in commercial papers + change in current portion of long-term loans payable + change in current portion of straight bonds and convertible bonds.

$D A C_{t}=$ discretionary accruals for year t estimated using the model in Dechow et al. (1995).

$I N V_{t}=\Delta$ Inventory in year $t-\Delta$ Sales in year $t$. The Inventory variable is merchandise and finished goods when available, total inventory otherwise.

$A R_{t}=\Delta$ Accounts receivable in year $t-\Delta$ Sales in year $t$. The Accounts receivable variable is accounts receivable when available, accounts and notes receivable otherwise.

$C A P X_{t}=\Delta$ Industry capital expenditure in year $t-\Delta$ Firm capital expenditure in year $t$. Industry capital expenditure $=$ aggregating capital expenditure for all firms with the same the Nikkei medium classification industry code. Firm capital expenditure $=$ change in gross property, plant, and equipment for a firm.

$G M_{t}=\Delta$ Sales in year $t-\Delta$ Gross margin in year $t$.

$S \& A_{t}=\Delta$ Selling and administrative expenses in year $t-\Delta$ Sales in year $t$.

$E T R_{t}=$ average effective tax rate from year $t-4$ to year $t-1-$ effective tax rate in year $t$. Effective tax rate $=$ income taxes $/$ income before income taxes. Each variable are acquired from the parent only financial statement.

$C T A C_{t}=($ total accruals for year $t$ minus total accruals for year $t-1) /$ total assets at the end of year $t$.

$A Q_{t}=$ dummy variable set to zero if auditor's opinion in year $t$ is unqualified, one if auditor's opinion is qualified or other.

$L F_{t}=($ sales revenue per employee for year $t-1$ - sales revenue per employee for year $t) /$ sales revenue per employee for year $t-1$. Sales revenue per employee $=$ sales $/$ the number of employees at year-end.

$B E T A_{t}=$ historical beta which is calculated using monthly returns over the 60 month period ending at the current fiscal year end $t$.

$S I Z E_{t}=$ natural log of market value of equity at the end of year $t$.

$B M_{t}=$ book value of equity at the end of year $t /$ market value of equity at the end of year $t$.

The definitions of all of the fundamental signals except for ETR and CTAC (i.e., INV, AR, CAPX, GM, $S \& A, A Q$, and $L F$ ) come from

Lev and Thiagarajan (1993). The $\Delta$ operator represents a percentage change in the percentage change in the variable based on two- 
year average expectation model, which is the same as that of prior studies (Lev and Thiagarajan, 1993; Abarbanell and Bushee, 1997). For example, $\Delta$ Sales in year $t=\left\{\right.$ Sales $_{\mathrm{t}}-\mathrm{E}\left(\right.$ Sales $\left.\left._{\mathrm{t}}\right)\right\} / \mathrm{E}\left(\right.$ Sales $\left._{\mathrm{t}}\right)$, where $\mathrm{E}\left(\right.$ Sales $\left._{\mathrm{t}}\right)=\left(\right.$ Sales $_{\mathrm{t}-1}+$ Sales $\left._{\mathrm{t}-2}\right) / 2$. All other variables with $\Delta$ operator in this paper are calculated as the same procedure.

All variables are winsorized at one percent by year.

$t$-statistics are corrected for heteroskedasticity, and cross-sectional and time-series correlation using a two-way cluster at the firm and year level proposed by Petersen (2009).

*** Statistically significant at the 0.01 level of significance using a two-tailed $t$-test

** Statistically significant at the 0.05 level of significance using a two-tailed $t$-test

* Statistically significant at the 0.1 level of significance using a two-tailed $t$-test 
Table 10 Size-adjusted abnormal return for $D F$ portfolio around subsequent forecast revision announcement

\begin{tabular}{ccc}
\hline Portfolio & & Ranked by $D F_{t}$ \\
Ranking & & FRRET $T_{t+1}$ \\
Lowest $(-)$ & & 0.004 \\
2 & 0.007 \\
3 & 0.005 \\
4 & 0.002 \\
5 & 0.002 \\
6 & -0.002 \\
7 & -0.004 \\
8 & -0.006 \\
9 & -0.003 \\
Highest $(+)$ & -0.014 \\
Hedge & $0.018^{* * *}$ \\
$(t$-value $)$ & $(3.166)$ \\
$N$ & 6,930 \\
\hline Note: & &
\end{tabular}

$F R R E T_{t+1}=$ the sum of the size-adjusted abnormal return around subsequent forecast revision announcement. Stock returns around forecast revision announcement are measured as the compounded stock returns earned over the 3-day window surrounding each forecast revision announcement (days from " 0 " to " +2 ") minus the compounded value-weighted return on a size-matched portfolio earned over the same window.

$D F_{t}=$ forecast innovation $\left(F I_{t}\right)$ minus nondiscretionary forecasts $\left(N D F_{t}\right) . F I_{t}=($ management forecasts for year $t+1$ minus actual net income for year $t$ ) / total assets at the end of year $t-1 . N D F_{t}=$ nondiscretionary forecasts / total assets at the end of year $t-1$.

*** Statistically significant at the 0.01 level of significance using a two-tailed $t$-test 
Table 11 Regressions of size-adjusted abnormal returns around subsequent forecast revision announcement on discretionary forecasts

\begin{tabular}{|c|c|c|c|}
\hline \multirow{3}{*}{$\begin{array}{c}\text { Independent } \\
\text { variable }\end{array}$} & \multicolumn{3}{|c|}{ Dependent variable $=F R R E T_{t+1}$} \\
\hline & $\begin{array}{l}\text { Expected } \\
\text { sign }\end{array}$ & \multicolumn{2}{|c|}{ Model (9) } \\
\hline & & Coefficient & $t$-value \\
\hline Constant & $?$ & $0.017 * *$ & $(2.174)$ \\
\hline$D F_{t}$ & - & $-0.145^{* * *}$ & $(-4.204)$ \\
\hline$N D F_{t}$ & $?$ & -0.065 & $(-0.499)$ \\
\hline$I N V_{t}$ & - & -0.001 & $(-0.181)$ \\
\hline$A R_{t}$ & - & -0.000 & $(-0.011)$ \\
\hline$C A P X_{t}$ & - & $-0.000^{*}$ & $(-1.842)$ \\
\hline$G M_{t}$ & - & -0.021 & $(-1.361)$ \\
\hline$S \& A_{t}$ & - & -0.025 & $(-1.566)$ \\
\hline ETR & - & 0.001 & $(0.290)$ \\
\hline$C T A C_{t}$ & - & $-0.046 * *$ & $(-2.048)$ \\
\hline$A Q_{t}$ & - & $0.017 * * *$ & $(2.848)$ \\
\hline$L F_{t}$ & - & $-0.028 *$ & $(-1.808)$ \\
\hline$B E T A_{t}$ & + & $-0.006 * *$ & $(-2.039)$ \\
\hline$S I Z E_{t}$ & - & -0.001 & $(-1.610)$ \\
\hline$B M_{t}$ & + & 0.001 & $(0.405)$ \\
\hline Adj. $R^{2}$ & & 0.011 & \\
\hline$N$ & & 6,930 & \\
\hline
\end{tabular}

$F R R E T_{t+1}=$ the sum of the size-adjusted abnormal return around subsequent forecast revision announcement. Stock returns around forecast revision announcement are measured as the compounded stock returns earned over the 3-day window surrounding each forecast revision announcement (days from " 0 " to " +2 ") minus the compounded value-weighted return on a size-matched portfolio earned over the same window.

$D F_{t}=$ forecast innovation $\left(F I_{t}\right)$ minus nondiscretionary forecasts $\left(N D F_{t}\right) . F I_{t}=$ (management forecasts for year $t+1$ minus actual net income for year $t$ ) / total assets at the end of year $t-1 . N D F_{t}=$ nondiscretionary forecasts / total assets at the end of year $t-1$.

$N D F_{t}=$ nondiscretionary forecasts / total assets at the end of year $t-1$.

$I N V_{t}=\Delta$ Inventory in year $t-\Delta$ Sales in year $t$. The Inventory variable is merchandise and finished goods when available, total inventory otherwise.

$A R_{t}=\Delta$ Accounts receivable in year $t-\Delta$ Sales in year $t$. The Accounts receivable variable is accounts receivable when available, accounts and notes receivable otherwise.

$C A P X_{t}=\Delta$ Industry capital expenditure in year $t-\Delta$ Firm capital expenditure in year $t$. Industry capital expenditure $=$ aggregating capital expenditure for all firms with the same the Nikkei medium classification industry code. Firm capital expenditure $=$ change in gross property, plant, and equipment for a firm.

$G M_{t}=\Delta$ Sales in year $t-\Delta$ Gross margin in year $t$.

$S \& A_{t}=\Delta$ Selling and administrative expenses in year $t-\Delta$ Sales in year $t$.

$E T R_{t}=$ average effective tax rate from year $t-4$ to year $t-1$ - effective tax rate in year $t$. Effective tax rate $=$ income taxes $/$ income before income taxes. Each variable are acquired from the parent only financial statement.

$C T A C_{t}=($ total accruals for year $t$ minus total accruals for year $t-1) /$ total assets at the end of year $t$. Total accruals are calculated as follows. Total accruals $=$ (change in current assets - change in cash and deposits $)-($ change in current liabilities - change in financing items) - (change in allowance for doubtful debts + change in provision for retirement benefits or provision for retirement allowance + change in provision for directors' retirement benefits + change in other long-term provision + depreciation). Financing items $=$ change in short-term loans payable + change in commercial papers + change in current portion of long-term loans payable + change in current portion of straight bonds and convertible bonds.

$A Q_{t}=$ dummy variable set to zero if auditor's opinion in year $t$ is unqualified, one if auditor's opinion is qualified or other.

$L F_{t}=($ sales revenue per employee for year $t-1$ - sales revenue per employee for year $t) /$ sales revenue per employee for year $t-1$. Sales revenue per employee $=$ sales $/$ the number of employees at year-end.

$B E T A_{t}=$ historical beta which is calculated using monthly returns over the 60 month period ending at the current fiscal year end $t$.

$S I Z E_{t}=$ natural log of market value of equity at the end of year $t$.

$B M_{t}=$ book value of equity at the end of year $t /$ market value of equity at the end of year $t$.

The definitions of all of the fundamental signals except for ETR and CTAC (i.e., INV, AR, CAPX, GM, S\&A, $A Q$, and $L F$ ) come from Lev and Thiagarajan (1993). The $\Delta$ operator represents a percentage change in the percentage change in the variable based on twoyear average expectation model, which is the same as that of prior studies (Lev and Thiagarajan, 1993; Abarbanell and Bushee, 1997). For example, $\Delta$ Sales in year $t=\left\{\right.$ Sales $_{\mathrm{t}}-\mathrm{E}\left(\right.$ Sales $\left.\left._{\mathrm{t}}\right)\right\} / \mathrm{E}\left(\right.$ Sales $\left._{\mathrm{t}}\right)$, where $\mathrm{E}\left(\right.$ Sales $\left._{\mathrm{t}}\right)=\left(\right.$ Sales $_{\mathrm{t}-1}+$ Sales $\left._{\mathrm{t}-2}\right) / 2$. All other variables with $\Delta$ operator in this paper are calculated as the same procedure. 
All variables are winsorized at one percent by year.

$t$-statistics are corrected for heteroskedasticity, and cross-sectional and time-series correlation using a two-way cluster at the firm and year level proposed by Petersen (2009).

*** Statistically significant at the 0.01 level of significance using a two-tailed $t$-test

** Statistically significant at the 0.05 level of significance using a two-tailed $t$-test

* Statistically significant at the 0.1 level of significance using a two-tailed $t$-test 
Figure 1 Size-adjusted abnormal returns produced by $D F$ trading strategies Panel A: Size-adjusted abnormal returns for highest and lowest DF ranking portfolio

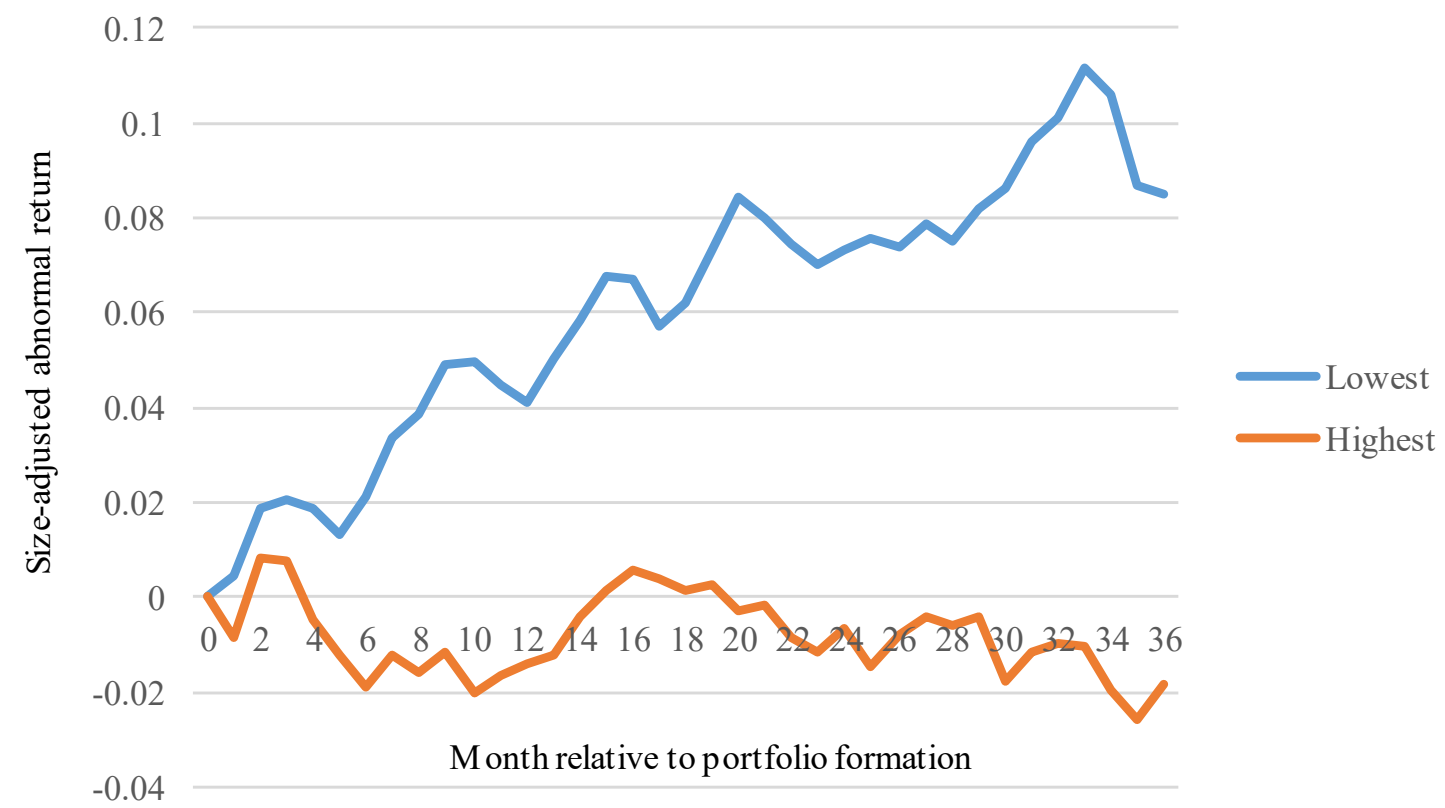

Panel B: Hedge portfolio returns produced by DF trading strategies

0.14

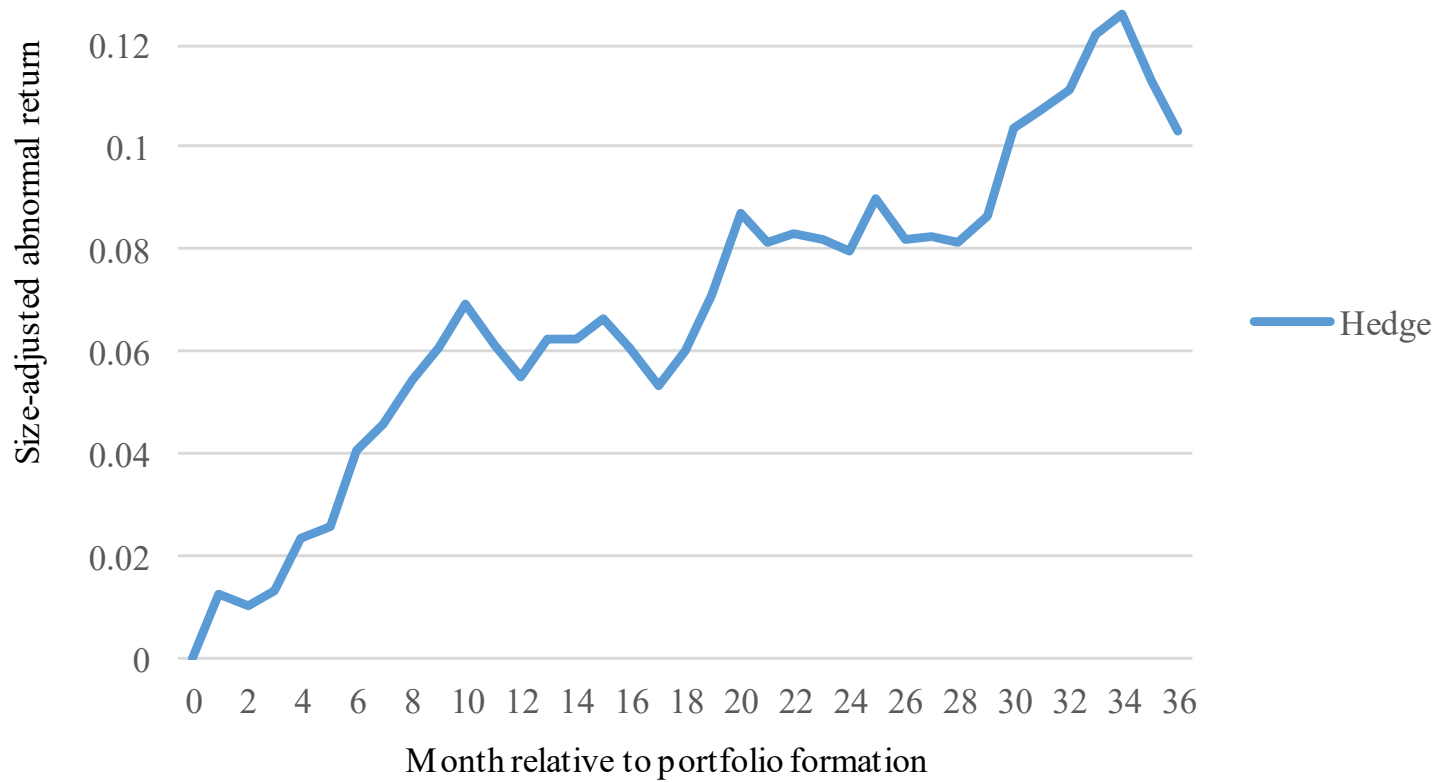

Note:

Size-adjusted abnormal returns are calculated as the buy-and-hold return on the security (including dividends) beginning at the start of the 4 month after fiscal year end $t$ and ending at the end of the indicated month (i.e., from month " 1 " to " 36 ") less the buy-and-hold return on a size-matched portfolio over the same period. 